\title{
The viability of the crustacean Eurycercus lamellatus (Branchiopoda, Cladocera) in a high mountain area in southern Norway
}

\author{
Tore Qvenild' and Trygve Hesthagen ${ }^{2}$
}

Qvenild T. and Hesthagen T. 2020. The viability of the crustacean Eurycercus lamellatus (Branciopoda, Cladocera) in a high mountain area in southern Norway. Fauna norvegica 40: $22-42$.

\begin{abstract}
The branchiopod Eurycercus lamellatus is widely distributed in Norwegian lakes, ranging from coastal to alpine areas. On the Hardangervidda mountain plateau in southern Norway, E. lamellatus was searched for in 144 lakes in 11 catchments in the western and 16 catchments in the central and eastern areas. The occurrence of E. lamellatus is mainly based on the diet of brown trout Salmo trutta. Eurycercus lamellatus was recorded in $25 \%$ and $70 \%$ of the lakes in these two areas, respectively. This may be due to striking differences in the environmental conditions, with more dilute water and lower water temperatures in western areas, and hence shorter growing seasons. The occurrence of E. lamellatus in central and eastern catchments increased with lake size, being found in $65 \%$ and $85 \%$ of lakes with a surface area of $<2.0$ and $\geq 2.0 \mathrm{~km}^{2}$, respectively. In the western area, E. lamellatus occurred less frequently in lakes above $1000 \mathrm{~m}$ a.s.l., which was not the case in central and eastern catchments. In this central part of Hardangervidda, the relative abundance of E. lamellatus in the diet of brown trout was studied more thoroughly in five different lakes, showing that they were preyed upon throughout the growing season (June to October). When the two big crustaceans Gammarus lacustris and Lepidurus arcticus are at low densities in these lakes, E. lamellatus became the staple food item for brown trout, except for larger fish $(>400 \mathrm{~mm})$. However, under high predation pressure, E. lamellatus also contributed significantly to the diet of larger fish. The abundance of $E$. lamellatus seems to vary highly on a yearly basis in one of the lakes (Sandvatn). Even though E. lamellatus is described as a typical littoral species, it was commonly found down to depths of $15 \mathrm{~m}$.
\end{abstract}

doi: 10.5324/fn.v40i0.3340. Received: 2019-11-06. Accepted: 2020-02-17. Published online: 2020-03-31. ISSN: $1891-5396$ (electronic).

Keywords: Eurycercus lamellatus, distribution, Hardangervidda, environmental conditions, brown trout diet

1. County Governor of Innlandet, Statens hus, Parkgata 36, NO-2306 Hamar, Norway

2. Norwegian Institute for Nature Research (NINA), PO box 5685, Torgården, NO-7485 Trondheim

Corresponding author: Tore Qvenild

E-mail:fmhetq@fylkesmannen.no

\section{INTRODUCTION}

The branchiopod Eurycercus lamellatus (O.F. Müller, 1776) is widely distributed in Norwegian lakes, being recorded in $37 \%$ of all localities investigated (Walseng 2015). It is frequently found in lakes from sea level up to 1355 m a.s.l. (Sandøy \& Nilssen 1986; Walseng 2015). Eurycercus lamellatus occurs both in small fishless ponds and in larger lakes, although its occurrence appears to increase with lake size (Walseng 2015). Further, it also tolerates acid waters with low ionic content (Sandøy \& Nilssen 1986; Walseng 2015).

Hardangervidda is the most extensive mountain plateau in Europe, where the brown trout Salmo trutta Linnaeus, 1758 is an almost allopatric fish species. The lakes on Hardangervidda are rated among the best brown trout lakes in Norway, hosting large fish of high quality (Sømme 1941). A rich supply of crustacean food items such as Lepidurus arcticus (Pallas, 1793) and Gammarus lacustris G.O. Sars, 1863 is regarded as the main reason for prolonged growth of brown trout to sizes of one to three $\mathrm{kg}$ and even more (Huitfeldt-Kaas 1911; Dahl 1917; Sømme 1941). However, the smaller E. lamellatus may also be an extremely important food item for brown trout. In high mountain lakes, the life-cycle traits of E. lamellatus and its significance as fish food has been little focused on since the studies that were carried out on the north-eastern part of Hardangervidda in the early 1900s (Dahl 1917). He showed that fish predation had a major impact on these crustaceans. However, in lakes with good access to G. lacustris and L. arcticus, brown trout selectively graze on these two big food items rather than on the smaller E. lamellatus (Qvenild \& Rognerud 2018).

So far, only 23 localities with E. lamellatus have been noted in this area (Norwegian Biodiversity Information Centre, Artsdatabanken.no). It has a highly skewed geographic distribution, with almost all records from the central and eastern areas. The western areas receive much higher snow depositions than central and eastern areas (Qvenild \& Hesthagen 2019). This cause a delay in the ice break-up in western lakes, resulting in shorter growing seasons and lower water temperatures (Borgstrøm 2016). This, in addition to more electrolyte poor water low in calcium (Skjelkvåle \& Henriksen 1998), may cause more hostile conditions for E. lamellatus, as has 
been shown for L. arcticus (Qvenild \& Hesthagen 2019) and G. lacustris (Qvenild et al. 2020).

Proximity to species refugia and an adequate activity pattern may be crucial in optimising the survival of E. lamellatus under high predation pressure from fish. Their diurnal pattern of activity was demonstrated in a study of juvenile perch Perca fluviatilus Linnaeus, 1758 and roach Rutilus rutilus (Linnaeus, 1758) (Tewson et al. 2016). The habitat preferences and their pattern of activity was experimentally tested using different food sources and fish cues (Beklioglu \& Jeppesen 1999). Exposed to fish, E. lamellatus seeked to the bottom of the chambers (or to sediment), probably in an attempt to hide within the sediment to avoid predation. Low epiphyte abundance evidently increases their vulnerability to visually hunting fish.

Field studies have shown that E. lamellatus is a typical semibenthic and littoral species, being most abundant in shallow vegetated areas along the shoreline (Dahl 1917; Smirnov 1962; Koksvik 1995; Aase 2000; Örnólfsdóttir \& Einarsson 2004), but it is also common down to depths of $20 \mathrm{~m}$ (Dahl 1932). It is an efficient grazer on periphyton (Smirnov 1962; Koksvik 1995; Örnólfsdóttir \& Einarsson 2004), and may accumulate in enormous densities, especially in vegetated areas (Dahl 1913).

The main goal of this study was to outline the occurrence of $E$. lamellatus in lakes on Hardangervidda and gain knowledge of its environmental requirements in such high mountain lakes. Apparently, E. lamellatus is a viable species that is well adapted to a wide range of environmental conditions (Smirnov 1962, Aass 1969; Sandøy \& Nilssen 1986; Walseng 2015). It may therefore be a more important food source for fish than has been documented earlier, with a substantial ability to withstand high predation pressure. This may be the case in high mountain lakes in particular, when G. lacustris and L. arcticus are absent or occur at low densities. Even in more dense fish populations, E. lamellatus seems capable of withstanding heavy predation pressure (Qvenild \& Rognerud 2018). In lowland lakes in southern Norway, the big cladocerans Sida crystallina O.F.M. and E. lamellatus were heavily predated by introduced rudd Scardinius erythropthalmus (Linnaeus, 1758) in the littoral zone, hence being a strong competitor to young native perch and brown trout (Walseng \& Jensen 2018). The abundance of the littoral cladocereans $>1 \mathrm{~mm}$ were reduced but they were not exterminated. Also in Lake Takvatnet in North Norway, E. lamellatus comprised a comprehensive part of the littoral crustacean community despite of heavy fish predation (Aase 2000).

To elucidate the ability of E. lamellatus to withstand high predation pressure from brown trout, we analysed their diet from five lakes at the central part of the plateau throughout the growing season for 15 years (see Qvenild et al. 2018). In one of these lakes,

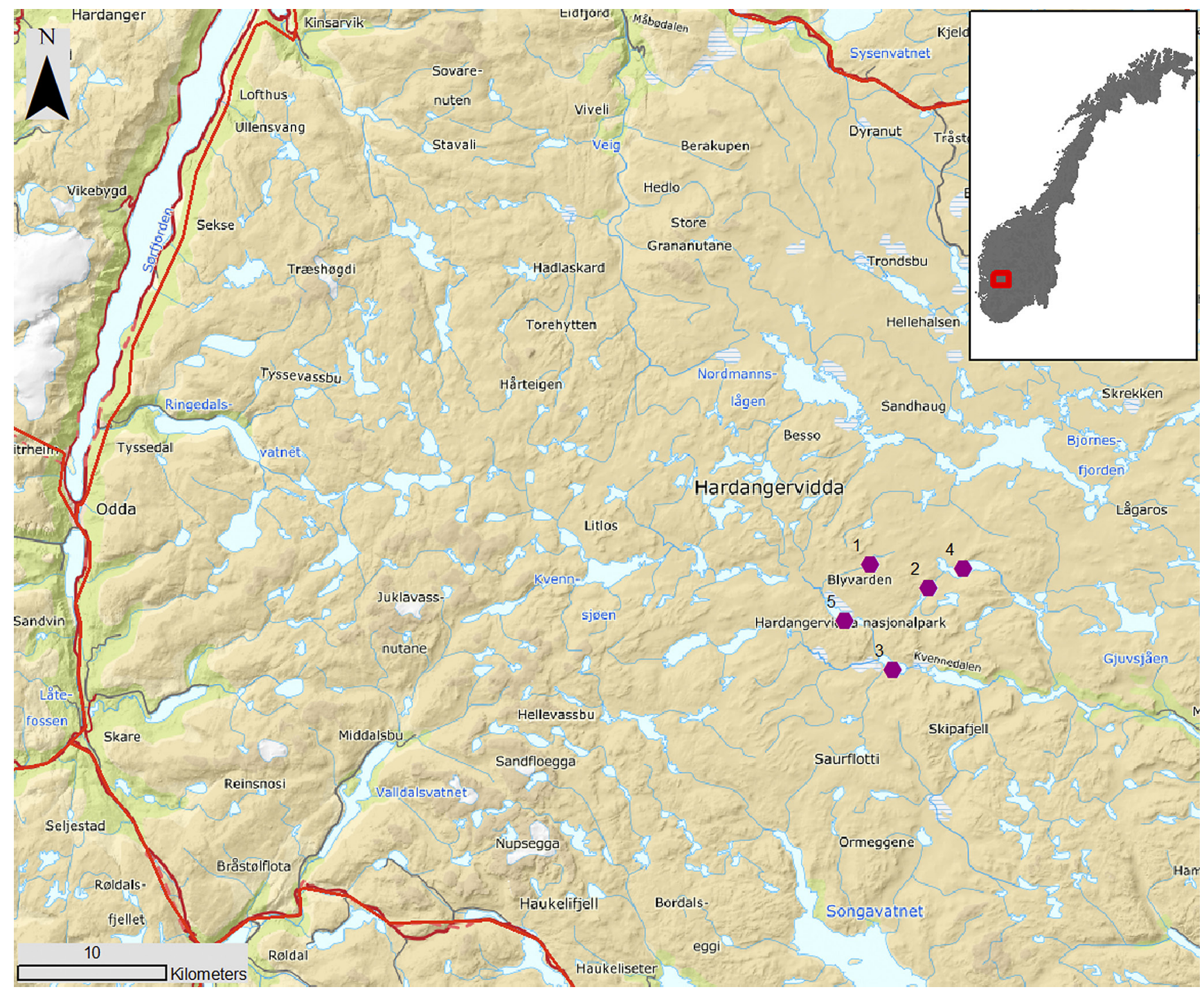

Figure I. Map showing the location of the five study lakes on Hardangervidda: 1) Blånuttjørnane, 2) Dargesjåen, 3) Gunleiksbuvatnet, 4) Fjellsjåen and 5) Sandvatn. Vital statistics for the lakes are given in Table 1. The Norwegian Mapping Authority CC BY 4.0. 
Table I. Vital statistics of the five study lakes. The statistics are given by the Norwegian Water Resources and Energy Directorate (NVE) and computed by the NEVINA procedure (NVE Atlas, nve.no), except for mean and maximum depth (own data). The lake area is included in the catchment which is computed with the outlet as set point in the NEVINA procedure. Lake number refers to the numbers given in Figure 1.

\begin{tabular}{|c|c|c|c|c|c|c|c|c|c|c|c|}
\hline $\begin{array}{l}\text { Lake } \\
\text { no. }\end{array}$ & $\begin{array}{l}\text { NVE } \\
\text { ID no. }\end{array}$ & Locality & $\begin{array}{l}\text { Altitude } \\
\text { m a.s.l. }\end{array}$ & Area km² & ${ }^{\circ} \mathrm{N}$ & ${ }^{\circ} \mathrm{E}$ & Catchment $\mathrm{km}^{2}$ & $\begin{array}{c}\text { Mean } \\
\text { depth }(\mathrm{m})\end{array}$ & $\begin{array}{c}\text { Max } \\
\operatorname{depth}(\mathrm{m})\end{array}$ & $\begin{array}{l}\text { Retention } \\
\text { time (days) }\end{array}$ & References \\
\hline 1 & 18770 & Blånuttjørnane & 1313 & 0.31 & 60.0883 & 7.5020 & 3.7 & 6.1 & 31 & 179 & $\begin{array}{l}\text { Rognerud et } \\
\text { al. } 2005\end{array}$ \\
\hline 2 & 18827 & Dargesjåen & 1209 & 0.64 & 60.0835 & 7.5866 & 15.7 & 4.7 & 15 & 66 & $\begin{array}{l}\text { Rognerud et } \\
\text { al. } 2006\end{array}$ \\
\hline 3 & 14 & $\begin{array}{l}\text { Gunleiksbu- } \\
\text { vatnet }\end{array}$ & 1076 & 1.29 & 60.0309 & 7.5655 & 434.6 & 2.9 & 12 & 2.5 & $\begin{array}{l}\text { Rognerud et } \\
\text { al. } 2003\end{array}$ \\
\hline 4 & 39 & Fjellsjåen & 1197 & 2.31 & 60.0958 & 7.6566 & 37.4 & 8.1 & 26 & 175 & $\begin{array}{l}\text { Rognerud et } \\
\text { al. } 2006\end{array}$ \\
\hline 5 & 17 & Sandvatn & 1112 & 1.57 & 60.0546 & 7.5111 & 288.2 & 2.6 & 13 & 3.9 & $\begin{array}{l}\text { Rognerud et } \\
\text { al. } 2005\end{array}$ \\
\hline
\end{tabular}

Table 2. The number of stomachs sampled from the five study lakes. In total 4.334 brown trout stomachs were examined in 100 dated test-fishing events. For details, see Appendix 2.

\begin{tabular}{|c|c|c|c|c|c|c|c|c|c|}
\hline \multirow[t]{2}{*}{ Lake } & \multirow[t]{2}{*}{ Zone } & \multirow[t]{2}{*}{ Period } & \multirow[t]{2}{*}{$\begin{array}{l}\text { No. of } \\
\text { events }\end{array}$} & \multicolumn{2}{|c|}{ No. of fish } & \multicolumn{2}{|c|}{$\begin{array}{c}\text { No. fish with } \\
\text { Eurycercus lamellatus }\end{array}$} & \multicolumn{2}{|c|}{ Frequency\% } \\
\hline & & & & $<250 \mathrm{~mm}$ & $\geq 250 \mathrm{~mm}$ & $<250 \mathrm{~mm}$ & $\geq 250 \mathrm{~mm}$ & $<250 \mathrm{~mm}$ & $\geq 250 \mathrm{~mm}$ \\
\hline Blånuttjørnane & Littoral & 2004 & 2 & 19 & 21 & 4 & 0 & 21 & 0 \\
\hline Dargesjåen & Littoral & 2003-2012 & 8 & 158 & 146 & 26 & 37 & 16 & 25 \\
\hline Fjellsjåen & Littoral & 2006-2012 & 10 & 154 & 312 & 32 & 36 & 21 & 12 \\
\hline Gunleiksbuvatn & Littoral & 2002 & 1 & 46 & 22 & 4 & 0 & 9 & 0 \\
\hline Sandvatn & Littoral & 2001-2016 & 61 & 1709 & 1205 & 440 & 205 & 26 & 17 \\
\hline Sandvatn & Profundal & 2001-2016 & 18 & 345 & 197 & 104 & 24 & 30 & 12 \\
\hline Total & & 2001-2016 & 100 & 2431 & 1903 & 610 & 302 & 25 & 16 \\
\hline
\end{tabular}

comparative test-fishing was carried out in the littoral and profundal zones for 12 years to elucidate their attraction to different habitats (see Qvenild \& Rognerud 2018).

\section{MATERIAL AND METHODS}

\section{Study area}

The Hardangervidda landscape is characterized by barren, treeless moorland interrupted by numerous pools, lakes, rivers and streams. The central part of this peneplain is a National Park. The main 27 catchments on the most central and remote parts of the plateau comprise an area of $6569 \mathrm{~km}^{2}$ (Qvenild \& Hesthagen 2019). In this area, 930 named lakes are identified (Norwegian Water Resources and Energy Directorate, NVE Atlas, nve.no), in which all the lakes are given their own NVE ID number. These localities also include 27 reservoirs for hydropower production that ranged in size from 0.39 to $78.77 \mathrm{~km}^{2}$ (Appendix 1). Their water level fluctuation ranged from 0.5 to $91.9 \mathrm{~m}$ annually, most of them being regulated by more than $10 \mathrm{~m}(76 \%)$ and $60 \%$ more than 20 m (cf. NVE Atlas, nve.no). In addition, there are approximately 11,600 small unnamed lakes and ponds covering $157 \mathrm{~km}^{2}$.

The western area of Hardangervidda is dominated by rocky terrain and expanses of bare rock with thin or no moraine-covered bedrock of Precambrian gneisses and granites and sparse or no vegetation. Some catchments in the central part comprise bedrock of CambroSilurian sedimentary origin. The bedrock in the eastern areas also covers gneisses and granites but has deeper layers of moraine. The water chemistry on Hardangervidda closely reflects the local bedrock geology (Skjelkvåle \& Henriksen 1998). Hence, the lakes are highly variable in water chemistry, ranging from lakes being practically free of electrolytes to lakes with high ionic strength. The content of total organic carbon (TOC) is generally low, due to the sparse vegetation and thin soil, with TOC $<1.6 \mathrm{mg} \mathrm{C} \mathrm{L}^{-1}$ in $75 \%$ of the lakes. In such clear-water lakes, calcium, magnesium and bicarbonate are the basic ions, reflected in $\mathrm{pH}$, alkalinity and conductivity. From the data given by Skjelkvåle \& Henriksen (1998) we estimated the relationship of conductivity $\chi$ (in $\mu \mathrm{S} \mathrm{cm}^{-1}$ ) and calcium concentration $\mathrm{Ca}$ (in $\mathrm{mg} \mathrm{L}^{-1}$ ) to be: $\mathrm{Ca}=1.7646^{*} \chi-0.6774\left(\mathrm{r}^{2}=0.987, \mathrm{~N}=117\right)$. The water quality in some of these lakes is repeatedly measured, and in such cases, the minimum values of calcium are used.

The climatic conditions on Hardangervidda are also highly variable (Qvenild \& Hesthagen 2019). The winter and summer depositions are computed using the NEVINA procedure (NVE Atlas, nve.no) as mean values for the normal period 1961-1990. The winter deposition (October-April) differs substantially in a west to east gradient with an almost four-fold decrease from $1151 \mathrm{~mm}$ in Austdølo/Ljoso catchment to $292 \mathrm{~mm}$ in Uvdalselvi catchment. The mean summer deposition (May-September) in these two catchments varied less; being 614 and $332 \mathrm{~mm}$, respectively. The mean winter and summer temperatures are computed similarly.

Brown trout is allopatric in most lakes on Hardangervidda. Arctic char Salvelinus alpinus (Linnaeus, 1758) occur in 3.1\% and the European minnow Phoxinus phoxinus (Linnaeus, 1758) in $4.5 \%$ of a total of 930 named lakes (Qvenild \& Hesthagen 2019). 
Distribution of Eurycercus lamellatus obtained from the literature

We searched for E. lamellatus in 144 lakes. (Appendix 1). Our main sources of information are technical reports and scientific papers. In most of these publications, the occurrence of E. lamellatus is mainly based on diet analyses of brown trout. In some lakes, other methods such as hauls and various types of bottom samplers, have also been used (Dahl 1917; Amundsen 1976; Halvorsen 1973; Walseng et al. 1994; Walseng et al. 1996; Fjellheim et al. 2007). The more basic fishery surveys provide detailed analyses of the different food items. In our context, the occurrence of E. lamellatus is noted as a positive finding when it is mentioned in the results of a survey. In lakes with negative findings, they may still occur (Dahl 1917). This is underlined by the results from lakes repeatedly examined that produced both positive and negative findings.

\section{Temporal variation in the abundance of Eurycercus lamellatus}

Field studies in five lakes in the Kvenna catchment in the central part of Hardangervidda were performed between 2001 and 2016 (Figure 1); Sandvatn, Fjellsjåen, Dargesjåen, Kringlesjåen and Blånuttjørnane (Qvenild \& Rognerud 2018; Qvenild et al. 2018). These lakes are situated at altitudes of 1076 to $1313 \mathrm{~m}$ a.s.l., being medium-sized with surface areas of $0.31-2.31 \mathrm{~km}^{2}$ and shallow with mean depths of 2.6-8.1 m (Table 1). These lakes contain sparse populations of allopatric brown trout. However, the 1997 year-class was extremely numerous, which caused a sharp rise in stock densities in the period 2004-2008, especially in Lake Sandvatn (Qvenild \& Rognerud 2018). The main crustacean food items in these study lakes, in addition to $E$. lamellatus, are L. arcticus and G. lacustris. Between 2001 and 2016 the diet of 3792 brown trout stomachs from 100 fishing events in the littoral zone in these five study lakes was analysed (Table 2, Appendix 2). To analyse the predation pressure from brown trout on these three crustaceans, we focused on the August-October period, when all species are available to be preyed upon. From this period, we obtained autumn diet of 3362 brown trout from the littoral zone, ranging in size between 110 and $470 \mathrm{~mm}$.

In one of the lakes, Lake Sandvatn, comparative test-fishing was performed both in the littoral (2-5 $\mathrm{m}$ depth) and profundal zones (12-15 m depth) in mid-August in 12 years from 2001 through 2016 (Table 5). From the littoral and profundal zones, 2914 and 542 brown trout stomachs were obtained, respectively (cf. Appendix 2).

\section{RESULTS}

Geographical distribution of Eurycercus lamellatus on Hardangervidda Of the 930 named lakes, $144(15 \%)$ have been fully examined for

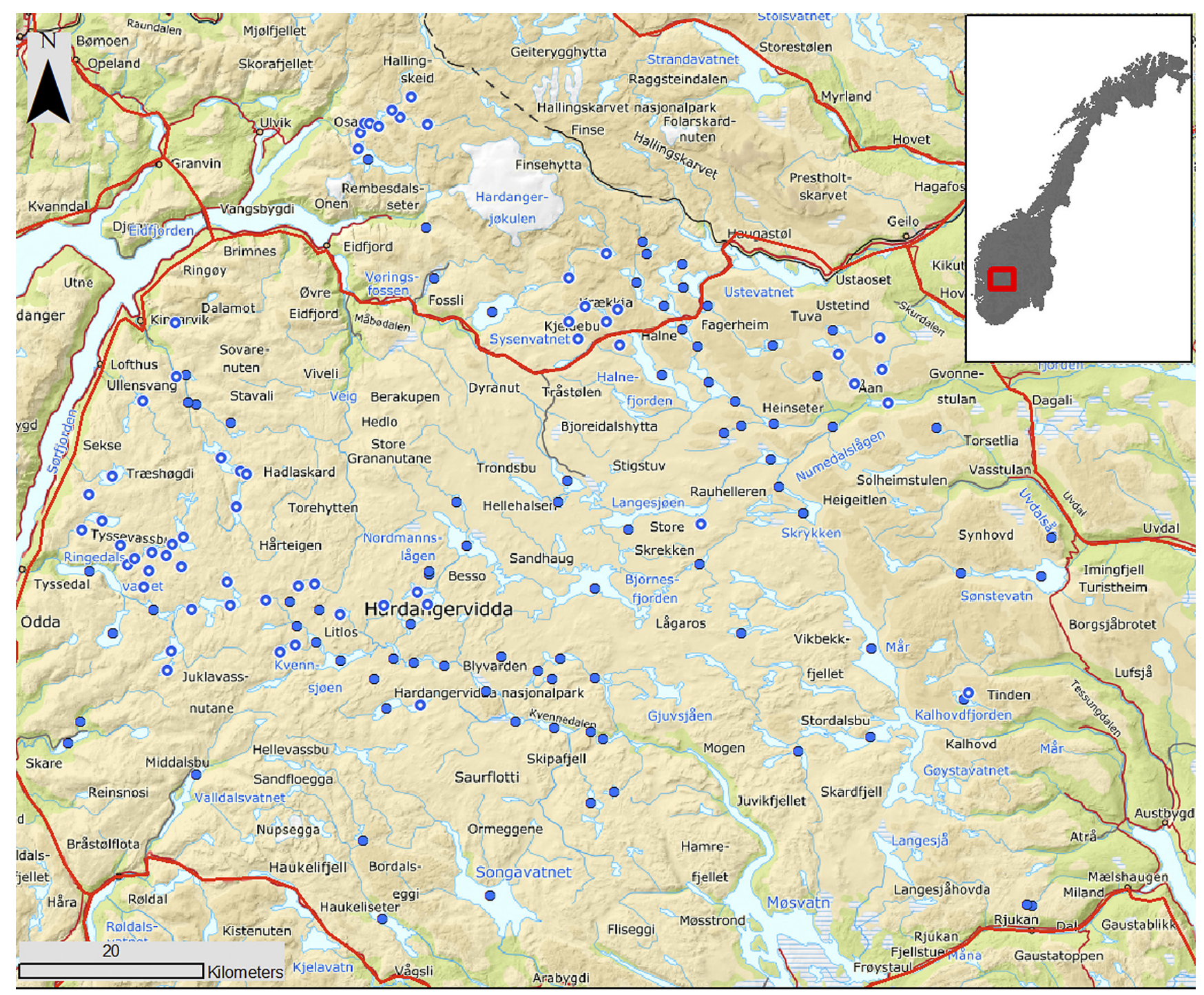

Figure 2. Lakes surveyed for the presence of Eurycercus lamellatus on Hardangervidda. Lakes with positive and negative findings are shown by filled and open dots, respectively. Details of the localities are given in Appendix 1. The Norwegian Mapping Authority CC BY 4.0. 
E. lamellatus, of which 83 lakes (58\%) produced positive findings (Figure 2, Appendix 1). Many of these localities have been repeatedly examined (Table 3). For example, Lake Sandvatn in the Kvenna catchment was studied for 15 years, all of which produced positive findings of E. lamellatus (Qvenild \& Rognerud 2018).

In the 16 central and eastern catchments, E. lamellatus was recorded in 73 of 104 lakes (70\%). In the lakes only sampled once, $E$. lamellatus was recorded in $52 \%$ of these cases. This fraction increased to $75 \%$ with two repeats. Lakes sampled more than two times, $E$. lamellatus was recorded in almost all (97\%). In the diet of brown trout from 40 lakes in the 11 western catchments, E. lamellatus was only recorded in ten of them (25\%). Many lakes in both areas have been repeatedly examined; i.e. a mean of 2.40 and 2.08 times, respectively.

Most of the named lakes are situated at altitudes of 1100-1399 m a.s.l. (85\%), while $11 \%$ and $4 \%$ are located at lower and higher altitudes, respectively. In this interval, we related the occurrence of $E$. lamellatus to lake altitude. In the 16 catchments in central and eastern parts of Hardangervidda, where it is a common food item for brown trout, there were only small variations in their occurrence at different altitudes (Table 4). In lakes located at 800 to $1099 \mathrm{~m}$ a.s.l. and at 1100 to $1399 \mathrm{~m}$ a.s.l., E. lamellatus was found in 85 and $68 \%$ of the lakes, respectively. Eurycercus lamellatus is a common species both in the lowest (Lake Isdalsvatnet at $832 \mathrm{~m}$ a.s.l.) and the highest located lake (Lake Vesle Meinsvatnet at $1353 \mathrm{~m}$ a.s.l.). Of the 755 lakes in this area, 53 are situated above $1353 \mathrm{~m}$ a.s.l., of which none was examined for E. lamellatus.

In the 11 western catchments, six of the ten lakes $(60 \%)$ located at altitudes lower than $1000 \mathrm{~m}$ a.s.l. had E. lamellatus, compared to only four of the 30 lakes (13\%) located higher than $1000 \mathrm{~m}$ a.s.l. (Table 4). In this area, Lake Nibbehølen is the highest situated lake (at 1191 m a.s.l.) with E. lamellatus. Of 155 lakes in this area, 93 of them are situated above $1191 \mathrm{~m}$ a.s.l. of which $16 \%$ were examined.

In the 95 natural lakes examined within the 16 central and eastern catchments, 75 had surface areas $<2.0 \mathrm{~km}^{2}$, in which E. lamellatus were found in $64 \%$. In the 20 lakes $\geq 2.0 \mathrm{~km}^{2}, 80 \%$ contained $E$. lamellatus. The species is also likely to occur in the remaining four lakes $\geq 2.0 \mathrm{~km}^{2}$ not examined in this area. However, the big lakes are more frequently investigated than the small ones. Of the lakes

Table 3. Percent of lakes examined for Eurycercus lamellatus in the 27 catchments studied on Hardangervidda. Only 144 lakes (15\%) are properly examined for Eurycercus lamellatus, of which $58 \%$ had positive findings. Many of the lakes are repeatedly investigated given with a factor in the last column ( $=$ no. of examinations/no. of lakes).

\begin{tabular}{|c|c|c|c|c|c|c|c|c|}
\hline No. & Catchment & $\begin{array}{l}\text { No. of } \\
\text { lakes }\end{array}$ & $\begin{array}{l}\text { No. of lakes } \\
\text { examined for } \\
\text { E. lamellatus }\end{array}$ & $\begin{array}{c}\% \text { of lakes } \\
\text { examined }\end{array}$ & $\begin{array}{l}\text { No. of lakes with } \\
\text { E. lamellatus }\end{array}$ & $\begin{array}{c}\% \text { of lakes } \\
\text { recorded }\end{array}$ & $\begin{array}{l}\text { No. of exam- } \\
\text { nations }\end{array}$ & $\begin{array}{c}\text { Repeatedly } \\
\text { examined }\end{array}$ \\
\hline 1 & Austdøla & 22 & 10 & 45 & 1 & 10 & 15 & 1.50 \\
\hline 2 & Sima & 14 & 1 & 7 & 1 & 100 & 2 & 2.00 \\
\hline $3 \mathrm{~A}$ & Isdølo & 6 & 1 & 17 & 1 & 100 & 2 & 2.00 \\
\hline 3B & Leiro & 22 & 8 & 36 & 1 & 13 & 10 & 1.25 \\
\hline $3 \mathrm{C}$ & Svinto & 2 & 0 & 0 & 0 & & 0 & \\
\hline 4 & Bjoreio & 14 & 2 & 14 & 2 & 100 & 3 & 1.50 \\
\hline 5 & Veig & 37 & 2 & 5 & 0 & 0 & 2 & 1.00 \\
\hline $6 \mathrm{~A}$ & Erdalsvassdraget & 2 & 0 & 0 & 0 & & 0 & \\
\hline $6 \mathrm{~B}$ & Bjotveitelvi & 2 & 0 & 0 & 0 & & 0 & \\
\hline $7 \mathrm{~A}$ & Kinso & 31 & 9 & 29 & 4 & 44 & 10 & 1.11 \\
\hline $7 \mathrm{~B}$ & Vivippo & 4 & 1 & 25 & 0 & 0 & 1 & 1.00 \\
\hline 8 & Opo & 10 & 1 & 10 & 0 & 0 & 1 & 1.00 \\
\hline $9 \mathrm{~A}$ & Espeelvi & 1 & 1 & 100 & 0 & 0 & 1 & 1.00 \\
\hline 9B & Vendo & 2 & 1 & 50 & 0 & 0 & 2 & 2.00 \\
\hline 10 & Tysso & 46 & 21 & 46 & 3 & 14 & 54 & 2.57 \\
\hline 11 & Austdølo/Ljoso & 13 & 2 & 15 & 2 & 100 & 2 & 1.00 \\
\hline 12 & Suldalsvassdraget & 7 & 1 & 14 & 1 & 100 & 2 & 2.00 \\
\hline 13 & Bora & 34 & 2 & 6 & 2 & 100 & 4 & 2.00 \\
\hline 14 & Songa & 44 & 1 & 2 & 1 & 100 & 6 & 6.00 \\
\hline 15 & Kvenna & 99 & 29 & 29 & 23 & 79 & 102 & 3.52 \\
\hline 16 & Møsvatn & 103 & 2 & 2 & 2 & 100 & 2 & 1.00 \\
\hline 17 & Mår/ Gøyst & 156 & 6 & 4 & 5 & 83 & 10 & 1.67 \\
\hline $18 \mathrm{~A}$ & Uvdalselvi & 39 & 4 & 10 & 4 & 100 & 8 & 2.00 \\
\hline $18 \mathrm{~B}$ & Ølmosåi & 37 & 0 & 0 & 0 & & 0 & \\
\hline $19 \mathrm{~A}$ & Lågen & 154 & 33 & $21 \%$ & 25 & 76 & 80 & 2.42 \\
\hline 19B & Ufysja & 10 & 3 & $30 \%$ & 1 & 33 & 5 & 1.67 \\
\hline \multirow[t]{2}{*}{20} & Ørteråni & 19 & 5 & $26 \%$ & 5 & 100 & 12 & 2.40 \\
\hline & TOTAL & 930 & 146 & $16 \%$ & 84 & 58 & 336 & 2.30 \\
\hline
\end{tabular}


Table 4. Frequency percent of lakes with Eurycercus lamellatus at different altitudes in 16 catchments located in central and eastern areas and 11 western catchments on Hardangervidda.

\begin{tabular}{lcccc}
\hline $\begin{array}{l}\text { Lakes with Eurycercus lamellatus from the } 16 \text { central and eastern } \\
\text { catchments: }\end{array}$ \\
\hline $\begin{array}{l}\text { Altitude } \\
\text { m a.s.1 }\end{array}$ & $\begin{array}{c}\text { No. of } \\
\text { lakes }\end{array}$ & $\begin{array}{c}\text { Examined } \\
\text { lakes }\end{array}$ & $\begin{array}{c}\text { Lakes with } \\
\text { E. lamellatus }\end{array}$ & $\begin{array}{c}\text { Frequency of } \\
\text { lakes with } E \text {. } \\
\text { lamellatus }(\%)\end{array}$ \\
\hline$<800$ & 0 & - & - & - \\
$800-899$ & 6 & 3 & 2 & 67 \\
$900-999$ & 16 & 5 & 4 & 80 \\
$1000-1099$ & 64 & 12 & 11 & 92 \\
$1100-1199$ & 270 & 52 & 36 & 69 \\
$1200-1299$ & 267 & 22 & 14 & 64 \\
$1300-1399$ & 140 & 10 & 7 & 70 \\
$1400-1499$ & 12 & 0 & 0 & - \\
$\geq 1500$ & 0 & - & - & - \\
\hline & 775 & 104 & 74 & 71 \\
\hline
\end{tabular}

Lakes with Eurycercus lamellatus from the 11 western catchments:

\begin{tabular}{lcccc}
\hline $\begin{array}{l}\text { Altitude } \\
\text { m a.s.1 }\end{array}$ & $\begin{array}{c}\text { No. of } \\
\text { lakes }\end{array}$ & $\begin{array}{c}\text { Examined } \\
\text { lakes }\end{array}$ & $\begin{array}{c}\text { Lakes with } \\
\text { E. lamellatus }\end{array}$ & $\begin{array}{c}\text { Frequency of } \\
\text { lakes with } E \text {. } \\
\text { lamellatus (\%) }\end{array}$ \\
\hline$<800$ & 6 & 5 & 4 & 80 \\
\hline $800-899$ & 5 & 2 & 2 & 100 \\
\hline $900-999$ & 10 & 3 & 0 & 0 \\
$1000-1099$ & 14 & 5 & 0 & 0 \\
$1100-1199$ & 34 & 10 & 4 & 40 \\
$1200-1299$ & 46 & 9 & 0 & 0 \\
$1300-1399$ & 34 & 6 & 0 & 0 \\
$1400-1499$ & 5 & 0 & 0 & \\
\hline 1500 & 1 & 0 & 0 & 25 \\
\hline & 155 & 40 & 10 & \\
\hline
\end{tabular}

examined one to two times or more than two times, the mean area was $1.15 \mathrm{~km}^{2}(\mathrm{~N}=68, \mathrm{SD} \pm 1.67)$ and $2.89 \mathrm{~km}^{2}(\mathrm{~N}=27, \mathrm{SD} \pm 3.85)$, respectively.

The incidence of E. lamellatus increased significantly with lake size as shown by a logistic regression: $p$ (occurrence $)=(1+\exp (0.848+$ $0.910 \cdot \log$ Area) $)^{-1}\left(\right.$ likelihood-ratio chi-square test: $\chi^{2}=4.39 p=0.036$ ) (Figure 3).

The calcium concentration is assumed to be the most important water chemistry variable for crustacean growth (Rukke 2002). We have minimum measures of calcium concentration in 58 of $83(70 \%)$ localities with positive findings of E. lamellatus of which $39 \%$ had calcium concentrations below $1.00 \mathrm{mg} \mathrm{L}^{-1}$ (cf. Appendix 1).

In the central and eastern areas, 73 of 104 (70\%) localities had positive findings of E. lamellatus. Of the 51 localities with calcium values, $18(35 \%)$ had lower values than $1.00 \mathrm{mg} \mathrm{L}^{-1}$. The lowest value of $0.28 \mathrm{mg} \mathrm{L}^{-1}$ was obtained in Lake Svartevasstjørni in 1994, which was prior to the liming programme that started in 1994 (Fjellheim et al. 2002). During this early phase of acid precipitation, E. lamellatus was present in the lake. This is the lowest calcium concentration measured in any lake with positive records of E. lamellatus on Hardangervidda.

Of the 10 localities with E. lamellatus in the western area, water chemistry data are available from seven lakes, of which five had calcium concentration less than $1.00 \mathrm{mg} \mathrm{L}^{-1}$.

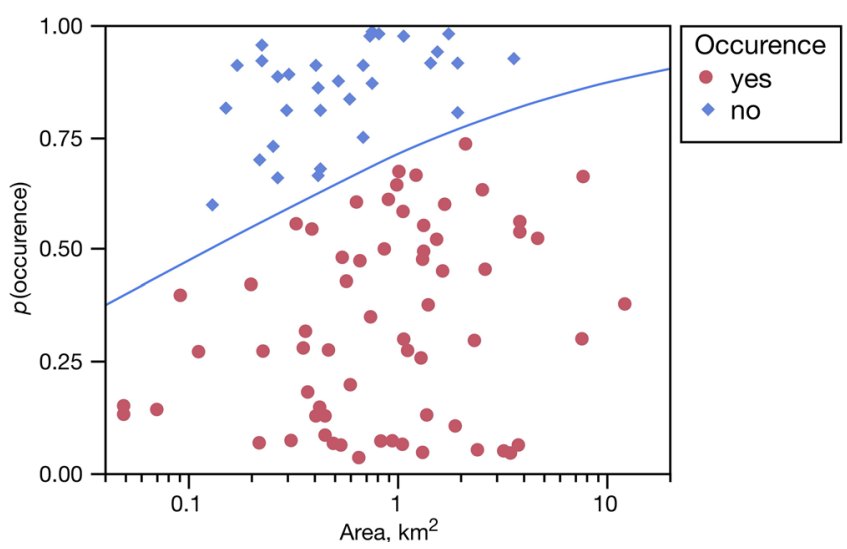

Figure 3. Logistic regression curve showing the probability of occurrence of Eurycercus lamellatus as a function of lake surface area. Of the 95 natural lakes studied within the 16 central and eastern catchments, Eurycercus lamellatus was found in $80 \%$ of the 20 lakes $>2.0 \mathrm{~km}^{2}$, while the species was found in only $64 \%$ of 75 lakes $<2.0 \mathrm{~km}^{2}$.

\section{The occurrence of Eurycercus lamellatus in reservoirs}

Most of the 27 reservoirs within the study area have been repeatedly investigated, on average more than three times. Eurycercus lamellatus was searched for in 24 of these reservoirs, $67 \%$ of which had positive findings. In the central and eastern catchments, E. lamellatus was registered in all the nine reservoirs examined. In the western catchments, however, E. lamellatus was recorded in only seven of the $15(47 \%)$ reservoirs examined. This included also Lake Ringedalsvatnet reservoir with a water amplitude of $91.9 \mathrm{~m}$.

\section{Eurycercus lamellatus in the diet of brown trout}

The diet of 3.792 brown trout from the littoral zone of the five study lakes was analysed, in which E. lamellatus was found in $784(21 \%)$ of them (cf. Table 2). The earliest record was from Lake Dargesjåen on 17 June 2004. The water temperature on that date was $9.0^{\circ} \mathrm{C}$, and only 56 degree-days since spring turnover at $4^{\circ} \mathrm{C}$ were achieved. In Lake Blånuttjørnane, E. lamellatus was noted on 18 June 2004, with a water temperature of $6.2^{\circ} \mathrm{C}$ and with only 44 degree-days since spring turnover. This was the earliest period of test-fishing. Six more fishing events were performed later in June in some of the lakes (cf. Appendix 2). However, no E. lamellatus were recorded, although most of the lakes had slightly higher water temperatures than the two localities with positive records. None of the lakes were fished in July, and most of the samples are from August and September, all with frequent records of E. lamellatus. The latest test-fishing in the fall was from Lake Fjellsjåen, on 2 October in 2006 and 2009, and both events recorded E. lamellatus.

As no test-fishing was performed in July, we used occurrence data for E. lamellatus from different published sources. Positive findings that month were registered in 25 different lakes within our study area (Amundsen 1976; Borgstrøm \& Sporan 1998; Jensen 1975; Madsen 1970, 1971, 1980; Myrvang \& Slettebø 2013; Qvenild 1978; Vasshaug 1970). The studies covered the following lakes (with NVE ID number): 23143 Ljosevatn, 393 Dragøyfjorden, 17040 Svartevatnet, 17411 Hetjørni, 17826 Flotatjørni, 391 Veslekrækkja, 17305 Inste Olavsbuvatn, 17908 Langesjøtjørni, 17402 Dyratjørnane, 17617 Store Selstjørni, 17322 Skardstjørnane, 67975 Lægreidvatnet, 17291 Dalboretjern, 553 Ørteren, 394 Geitsjøen, 17612 Vesle Selstjørni, 17289 Halnetjørni, 1906 Isdalsvatnet, 414 Øvre Hein, 18581 Ambjørsvatnet, 1907 Sysenvatn and 17583 Nedre Hein.

In the August-October period, when all species are available to be 


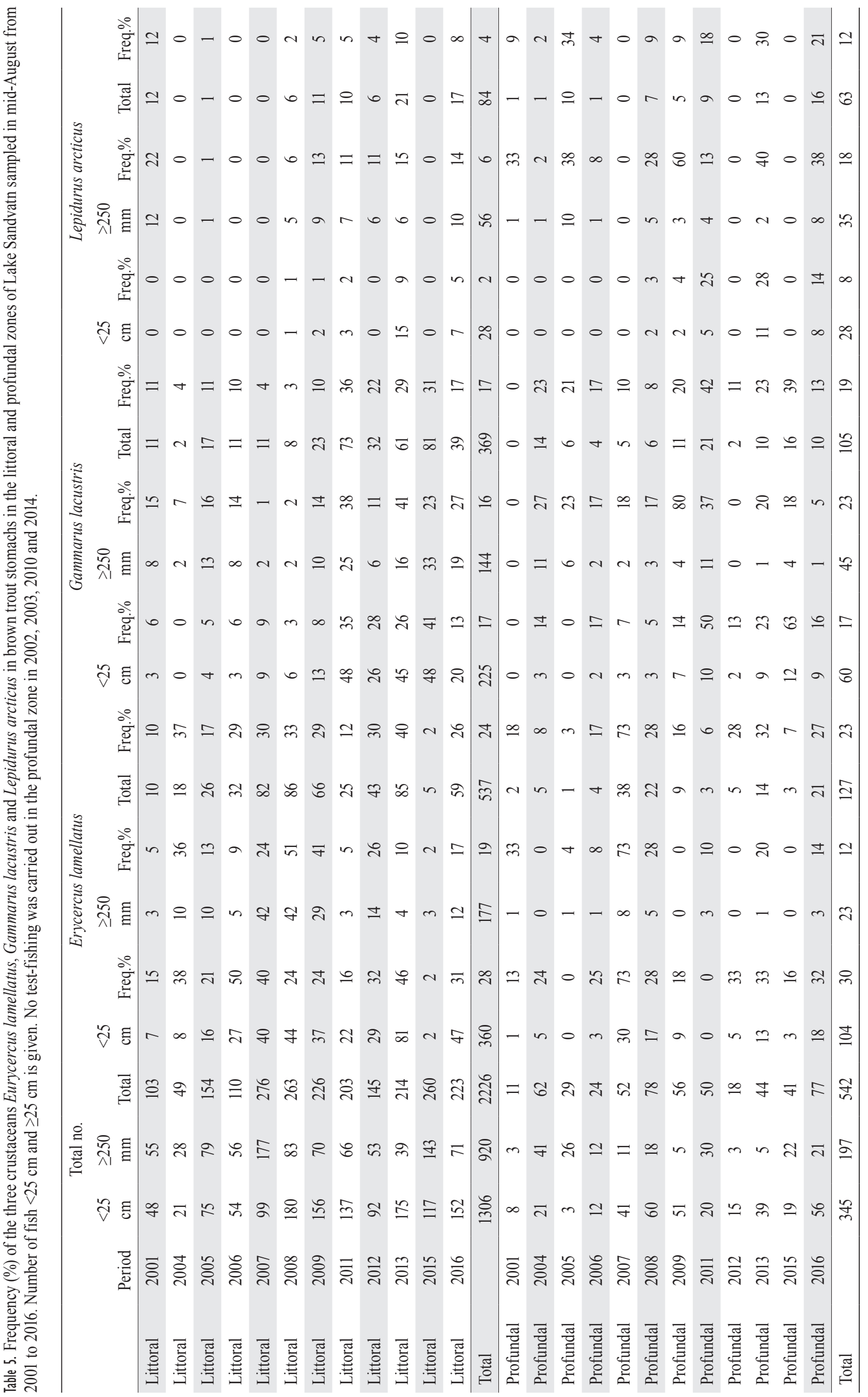




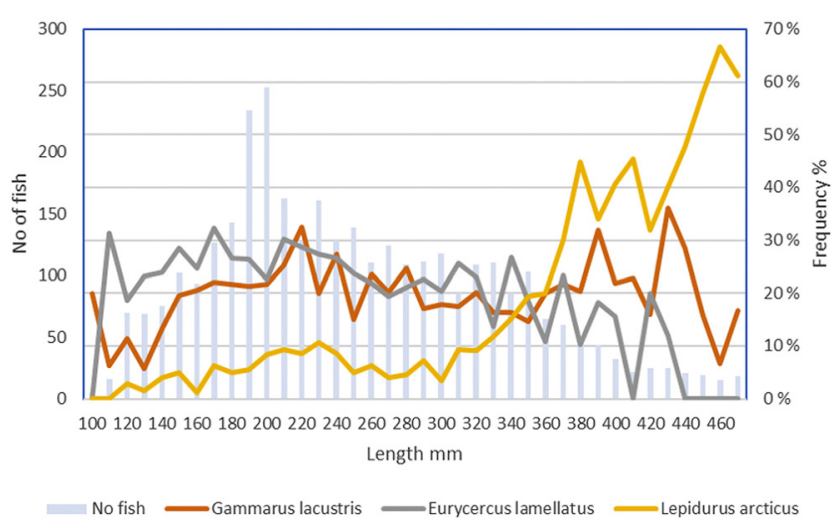

Figure 4. The frequency percent of Eurycercus lamellatus, Gammarus lacustris and Lepidurus arcticus in the diet of 3.362 brown trout from the littoral zone, ranging in size between 110 and $470 \mathrm{~mm}$, from the five study lakes sampled during the period 8 August to 2 October in 2001-2016.

preyed upon, E. lamellatus was an important food item among most size-groups of brown trout, with an occurrence frequency of mainly $20-30 \%\left(F_{1,35}=54.75, p<0.0001, r^{2}=0.60\right)$ (Figure 4). However, they became less important as food for fish with a length of $400-470 \mathrm{~mm}$. The opposite trend was revealed for $L$. arcticus, which became more important as a food item as fish size increase $\left(F_{1,35}=106.23, p<0.0001\right.$, $\left.r^{2}=0.74\right)$. Only $4.3 \%$ of brown trout $<200 \mathrm{~mm}(\mathrm{~N}=934)$ had preyed upon $L$. arcticus, as opposed to $48.0 \%$ of fish $\geq 400 \mathrm{~mm}(\mathrm{~N}=196)$. Gammarus lacustris was equally important as a food item for brown trout in all size groups $(p>0.05)$.

The comparative test-fishing in the littoral and profundal zones in Lake Sandvatn revealed that E. lamellatus and G. lacustris was common in the diet of brown trout in both zones (Table 5). However, their abundance varied substantially on a yearly basis in both zones; their mean occurrence $( \pm$ SD) were $24 \pm 12 \%$ vs. $17 \pm 11 \%$ and $23 \pm 19 \%$ vs. $19 \pm 12 \%$, respectively. The variations in abundance in these two zones was not significantly different (independent-sampled t-test, $p>0.05)$. However, L. arcticus was more abundant in the profundal $(11 \pm 12 \%)$ than in the littoral zone $\left.(4 \pm 4 \%) ; \mathrm{F}_{1,22}=10.34, p<0.005\right)$.

\section{DISCUSSION}

Eurycercus lamellatus is widely distributed in Norwegian lakes, indicating that the species is well adapted to a wide range of environmental conditions (Walseng 2015). As a relatively large Cladocera (up to $4 \mathrm{~mm}$ ), it has proved to be one of the most important food items for brown trout in the lakes on Hardangervidda, together with G. lacustris and L. arcticus (Dahl 1913, 1917; Sømme 1941). So far, there has been limited focus on E. lamellatus. In order to evaluate their occurrence on Hardangervidda, it was searched for in 144 lakes in 27 catchments covering an area of $6569 \mathrm{~km}^{2}$. On this mountain plateau, the environmental conditions are highly variable, with particularly harsh conditions in the 11 catchments in the western part, related to climatic conditions and water quality (Qvenild \& Hesthagen 2019). The lakes on Hardangervidda are situated at a wide range of altitudes and sizes and included also 27 reservoirs. Thus, the distribution pattern of E. lamellatus in this mountain area may improve the knowledge of their environmental demands.

\section{The significance of the sampling method}

The brown trout is an opportunistic feeder and its diet changes with the availability of food (Fjellheim et al. 2007; Qvenild \&
Rognerud 2018). Thus, the complex variation in the aquatic organism community may be reflected in their diet. Since L. arcticus is a highly preferred food item, analysing brown trout stomachs appears to be the most sensitive method for detecting their existence, especially at low densities (Fjellheim et al. 2007; Qvenild \& Hesthagen 2019). Thus, we employed the same method for detecting E. lamellatus. Even though the frequency some years was at low levels in Lake Sandvatn, the species was always detected.

One of the main constraints with regards detecting E. lamellatus is its small size (1-4 mm) compared to L. arcticus and G. lacustris. This makes it a less conspicuous species, easy to overlook when fish stomachs are checked in the field. In many studies focus is mainly given G. lacustris and L. arcticus and E. lamellatus may be noted together with other semi-benthic species as "zooplankton" or only grouped to "cladocerans". Thus, in less comprehensive studies, E. lamellatus may be omitted or not at all recorded.

The number of stomachs analysed in some lakes may also have been too few to detect E. lamellatus. In Lake Sandvatn, brown trout stomachs were repeatedly sampled in mid-August for 15 years, all with positive findings of E. lamellatus (Qvenild \& Rognerud 2018). However, their occurrence showed high yearly variations (range $2-40 \%$ ), indicating that sample size is crucial for a positive find. In 2015, 260 fish stomachs were analysed, and only five of them contained E. lamellatus (2\%).

In the lakes in the central and eastern catchments examined only once, E. lamellatus was found in about $50 \%$ of them. When individual lakes were sampled more than two times, E. lamellatus was recorded in almost all cases. Repeated examinations therefore seem to be essential.

\section{Eurycercus lamellatus - a highly preferred food item for fish}

The two large, nutrient-rich crustaceans, G. lacustris and L. arcticus, are known to be staple food items for brown trout in high mountain lakes, their preference reflecting the high quality of the fish (Dahl 1913, 1917; Sømme 1941). In this context, the smaller E. lamellatus is considered to be of secondary importance. To evaluate the effect of predation pressure on E. lamellatus, as well as on G. lacustris and L. arcticus, an extensive study of brown trout diet was carried out in five lakes by analysing 4.334 stomachs (cf. Qvenild et al. 2018). In these lakes, it was a heavy predation from smaller fish on $E$. lamellatus. However, larger fish also utilized them frequently. The relatively high importance for smaller fish has also been noted by Dahl (1932), Beklioglu \& Jeppesen (1999) and Walseng \& Jensen (2018). However, when densities of G. lacustris and L. arcticus are low, E. lamellatus may provide the staple food for brown trout, even for larger individuals. This was demonstrated in Lake Sandvatn in 2004-2008 when a dense brown trout population grazed the two big crustaceans to near extinction (cf. Appendix 2). This effect is best revealed when stomach fullness is checked. In this period, G. lacustris and $L$. arcticus accounted for 13 volume percent of the stomach content, compared to 41 volume percent for E. lamellatus (Qvenild $\&$ Rognerud 2018). When the brown trout population returned to its normal level in 2010-2016, the volume percent of G. lacustris and L. arcticus was $40 \%$, compared to $20 \%$ for E. lamellatus. It is worth mention that E. lamellatus seemed to be capable to withstand the grazing at all brown trout densities in the study lakes. This was also noted by Dahl (1917) when he compared the crustacean communities in 12 lakes on the northern fells of Hardangervidda. When they were abundant, brown trout preferred G. lacustris and L. arcticus rather than E. lamellatus, even when the latter species was very abundant.

As this study indicates, E. lamellatus tolerates heavy predation 
pressure from brown trout. This may be due to an adequate antipredator behaviour such as diel changes in activity, combined with good access to suitable refugia (Tewson et al. 2016; Beklioglu \& Jeppesen 1999). The preference for vegetated areas (Dahl 1913; Smirnov 1962; Koksvik 1995; Aase 2000; Örnólfsdóttir \& Einarsson 2004; Walseng 2015) may also be an adaptation to improve their survival. However, there are no specific areas with dense vegetation in Lake Sandvatn, and variation in the stomach content of brown trout indicated that clusters of E. lamellatus occurred throughout the lake.

In our study, the occurrence of E. lamellatus increased significantly with lake size. This distribution pattern was also pointed out by Walseng (2015), and it demonstrates that lake size is of great importance for sustaining vital populations of E. lamellatus. We assume access to refugia are better in large and deep lakes than in small and shallow ones. It should be added that bigger lakes are more frequently investigated.

\section{Spatial distribution}

In a national survey, E. lamellatus was frequently found in lakes from sea level up to $1355 \mathrm{~m}$ a.s.l. (Walseng 2015). However, at altitudes above $1000 \mathrm{~m}$ a.s.l., their occurrence was less than 30\%. In another national study (Sandøy \& Nilssen 1986), their occurrence was somewhat higher (41\%). In the 16 catchments in the central and eastern parts of Hardangervidda, E. lamellatus was recorded in 70\% of the lakes located higher than $1000 \mathrm{~m}$ a.s.l. Hence, their occurrence was much higher in this mountain area than revealed in the national surveys (Sandøy \& Nilssen 1986; Walseng 2015). In the western part of the plateau, only 40 lakes were investigated. Here, the abundance of E. lamellatus in lakes at altitudes higher than $1000 \mathrm{~m}$ a.s.l. was only $13 \%(\mathrm{~N}=30)$, compared to $60 \%$ in lakes at lower altitudes $(\mathrm{N}=10)$. This indicates that E. lamellatus respond negatively to the harsher and more hostile conditions in this area. Thus, the environmental conditions in lakes in the central and eastern part seem to be more favourable for E. lamellatus. The highest locality with E. lamellatus on Hardangervidda was Lake Vesle Meinsvatnet at $1353 \mathrm{~m}$ a.s.l. They may also exist in higher altitude lakes in this area. However, only $7 \%$ of the lakes are located at higher levels. To date, none of these lakes has been examined.

The general drop in air temperature of about $0.6{ }^{\circ} \mathrm{C} 100 \mathrm{~m}^{-1}$ altitude is reflected in the water temperature (Qvenild \& Hesthagen 2019). Water temperature is crucial to all aquatic ectotherms. It has a significant impact on growth, development and generation time of cladocerans (Bottrell 1975; Gillooly 2000). This was shown in Lake Myvatn on Iceland, where E. lamellatus reached its maximum abundance later in the cold summer of 1992 than in the previous warmer summer (Örnólfsdóttir \& Einarsson 2004). Delayed development was also indicated in our study, as E. lamellatus was barely noted in midAugust in the cold summer of 2015 (Table 5). There is a steep fall in snow deposition in a west to east gradient on Hardangervidda. Hence, the ice break-up will normally be significantly delayed in the western lakes, being colder and bringing a shorter ice-free season (Borgstrøm 2016; Qvenild \& Hesthagen 2019). Even though E. lamellatus seems to tolerate a wide range of temperature conditions, the western parts of Hardangervidda may be more marginal to the development of $E$. lamellatus.

In the national-wide surveys, the distribution of E. lamellatus indicated a high tolerance to water temperature extremes (Sandøy \& Nilssen 1986; Walseng 2015). It is noted that E. lamellatus may tolerate temperature well above $20^{\circ} \mathrm{C}$ (Smirnov 1962). However, there is a low probability of such extreme events in the lakes on Hardangervidda (Qvenild et al. 2018).
Besides the 930 named lakes on Hardangervidda, mainly with fish, there are a large number of small unnamed lakes and ponds, most of them without fish (Qvenild \& Hesthagen 2019). The resting eggs of E. lamellatus tolerate both freezing and drying (Dahl 1913; Aass 1969). In addition, they also have a high tolerance to acid water and different temperature conditions. Hence, E. lamellatus should be well adapted to small lakes and ponds (Walseng 2015). On Hardangervidda, only 16 unnamed lakes and ponds have been studied, four with positive findings of E. lamellatus (Halvorsen 1973; Walseng et al. 1994; Walseng et al. 1996: Fjellheim 2004). Nevertheless, the potential for positive findings of E. lamellatus in such small fishless lakes and ponds should be substantial. When fish is present, the role of refugia became more relevant.

In Lake Sandvatn, the littoral and profundal zones were comparatively fished for 12 years (Table 5, Appendix 2). Both $E$. lamellatus and G. lacustris occurred frequently in both zones. On the other hand, L. arcticus was more abundant in the profundal zone, presumably due to intense predation pressure from a dense brown trout population (2004-2008). Lake Sandvatn is shallow, like many lakes in the central and eastern parts of Hardangervidda (Qvenild \& Hesthagen 2019). In such lakes, E. lamellatus seems to be frequently abundant in different depth strata. This was also found in Lake Pålsbufjorden prior to the regulation in 1927 where E. lamellatus was commonly found down to depths of $20 \mathrm{~m}$ (Dahl 1932).

Eurycercus lamellatus seems to increase in abundance in reservoirs at a wide range of water amplitudes (Dahl 1926, 1930, 1932; Aass 1969). Within the study area on Hardangervidda, there are 27 reservoirs for hydropower production, ranging from 0.39 to 78.77 $\mathrm{km}^{2}$ in size and with amplitudes of 0.5 to $91.9 \mathrm{~m}$. In the reservoirs investigated $(\mathrm{N}=24), 67 \%$ had positive findings of E. lamellatus. All the reservoirs $(\mathrm{N}=9)$ in the central and eastern catchments had E. lamellatus, as opposed to $47 \%$ of the reservoirs $(\mathrm{N}=15)$ in western catchments. Eurycercus lamellatus has also been recorded in the Lake Ringedalsvatnet reservoir, with an annual water amplitude of $91.9 \mathrm{~m}$. This emphasises the remarkable capacity of E. lamellatus to adapt to new and unstable conditions (cf. Dahl 1926, 1932).

\section{Seasonal abundance of Eurycercus lamellatus}

There is limited evidence regarding the seasonal abundance of $E$. lamellatus in Norwegian lakes. It survives the winter as resting eggs and is thus not available as fish food during the winter (Dahl 1913, 1926, 1932; Aass 1969; Koksvik 1995). Eurycercus lamellatus is assumed to hatch early in spring (Dahl 1913, 1926; Smirnow 1962; Koksvik 1995; Aase 2000; Örnólfsdóttir \& Einarsson 2004). This is also confirmed by observations in two of our study lakes; detecting E. lamellatus on 17-18 June in 2004. In Lake Takvatnet, small E. lamellatus was observed near to ice break-up as early as 12 June at a temperature of $2.5^{\circ} \mathrm{C}$ (Aase 2000). Records of E. lamellatus in late June were also noted in Lake Mår in 2007, 2009, 2010 and 2011 (Rognerud \& Fjeld 2014).

As revealed in our study, E. lamellatus is usually present from August until October. Of the 3362 brown stomachs, 770 (23\%) contained E. lamellatus in this period. Many reports have also identified E. lamellatus as a common food item for brown trout in July on Hardangervidda. Throughout the summer, the abundance of E. lamellatus seem to increase until it culminates in late summer or early autumn on Hardangervidda. This was also the case in Lake Pålsbufjorden, an adjacent lake close to this mountain plateau, reaching maximum abundance in early September (Dahl 1932). The same pattern of seasonal abundance was also found in Lake Målsjøen (165 m a.s.l.) in central Norway (Koksvik 1995), in Lake Takvatn (214 
m a.s.l.) in northern Norway (Aase 2000) and in Lake Myvatn (277 m a.s.l.) on Iceland (Örnólfsdóttir \& Einarsson 2004). In all these lakes, E. lamellatus emerged early in June and reached maximum abundance from July until October. However, in colder high mountain lakes such as on Hardangervidda, we assume that E. lamellatus will reach their maximum abundance later than in low-land lakes.

\section{Environmental conditions may limit the distribution of Eurycercus lamellatus}

On Hardangervidda, E. lamellatus revealed a skewed geographical distribution in the 144 lakes examined. In the 16 catchments in the central and eastern areas, only $14 \%$ of the 105 lakes are examined. In $70 \%$ of them, E. lamellatus was recorded. As pointed out above, this percentage may easily be increased by repeated investigations. In the 11 western catchments, E. lamellatus was recorded in only $26 \%$ of the 41 sites examined, in spite of repeated investigations in many of them. Thus, E. lamellatus seems to be far less common to this area.

The catchments in the western area are extremely barren, with only a thin layer of moraine or glacio-fluvial deposits on Precambrian bedrock, and almost without vegetation, where the water is dilute and low in calcium (Skjelkvåle \& Henriksen 1998). On the other hand, the catchments in the central and eastern areas have a thicker moraine cover with more vegetation, providing water with a higher ionic content. The mean calcium concentrations in the lakes in western and central/ eastern areas were 0.80 and $1.80 \mathrm{mg} \mathrm{L}^{-1}$, respectively (Qvenild \& Hesthagen 2019). No threshold for the calcium demand of E. lamellatus has so far been established. In total, $40 \%$ of the 58 localities with positive findings of $E$. lamellatus had calcium concentration below 1.0 $\mathrm{mg} \mathrm{L}^{-1}$. The lowest value was $0.28 \mathrm{mg} \mathrm{L}^{-1}$, which was obtained in Lake Svartevasstjørni in 1994 prior to a liming programme (Fjellheim et al. 2002). Neither G. lacustris, L. arcticus nor E. lamellatus were detected in the diet of brown trout at that time. However, E. lamellatus quickly reappeared when the calcium level increased after liming (Fjellheim et al. 2002), demonstrating that E. lamellatus had survived this marginal water quality prior to this mitigation measure. This is the minimum level of calcium concentration measured in lakes on Hardangervidda hosting E. lamellatus.

These results indicate that E. lamellatus tolerates waters low in calcium. However, Sandøy \& Nilssen (1986) noted a preference for electrolyte-rich waters for their survival. As calcium is the major cation in lakes on Hardangervidda, there is a very close relationship between conductivity and calcium concentration as estimated from the data in Skjelkvåle \& Henriksen (1998). This reveals calcium concentrations $<1 \mathrm{mg} \mathrm{Ca} \mathrm{L}{ }^{-1}$ to be equivalent to conductivities $<9 \mu \mathrm{S} \mathrm{cm}^{-1}$. This place $40 \%$ of the localities in the lowest conductivity category in the national-wide survey of Sandøy \& Nilssen (1986), resulting in a consistently lower probability of supporting E. lamellatus. Rapid postmoult calcification of the exoskeleton is essential to all crustaceans (Rukke 2002). Hence, we can assume that low calcium concentrations also impede the process of ecdysis in E. lamellatus.

In spite of the apparently high tolerance of E. lamellatus to low water temperature and dilute waters, we assume that the combination of these two environmental factors contributes to their sparse occurrence in the lakes in the western areas of Hardangervidda compared to that in central and eastern parts of the mountain plateau. This may be reinforced in high altitude lakes with even lower temperatures as documented in western areas. Thus, this small crustacean seems to be more viable in harsh conditions compared to $L$. arcticus and G. lacustris earlier reported from the same area (Qvenild \& Hesthagen 2019; Qvenild et al. 2020).

\section{ACKNOWLEGDEMENTS}

The authors gratefully acknowledge Roar Kjær for drawing the maps and Eirik Fjeld for support with the statistical analyses.

\section{REFERENCES}

Aass P. 1969. Crustacea, especially Lepidurus arcticus Pallas, as brown trout food in Norwegian mountain reservoirs. Institute of Freshwater Research, Drottningholm. Report No 49, 1969: 183-201.

Aase BM. 2000. Litorale Cladocera (Crustacea) i Takvatn, Troms. MSc Thesis. Institutt for marin- og ferskvannsbiologi, Norges fiskerihøgskole. Univ. i Tromsø. 41 pp. (In Norwegian).

Amundsen T. 1976. Fiskeribiologiske undersøkelser for Dagalivassdraget 1974-75. Fiskerikonsulenten for Øst-Norge. Rapport Na IV-3.2. 285 pp. (In Norwegian).

Beklioglu M, Jeppesen E. 1999. Behavioural response of plant-associated Eurycercus lamellatus (O.F. Müller) to different food sources and fish cue. Aquatic Ecology 33: 167-173. doi: 10.1023/A:1009934828802

Borgstrøm R. 2016. Auren på Hardangervidda er sterkt påverka av klimatilhøve. Naturen nr. 4-2016: 147-155. (In Norwegian). doi: 10.18261/issn.1504-3118-2016-04-02

Borgstrøm R, Sporan NR. 1998. Prøvefiske i Ambjørnsvatn, Ullensvang Statsallmenning, i 1997. Bestandsanalyse og forslag til driftsplan. Norges landbrukshøgskole, Institutt for biologi og naturforvaltning. Fiskerapport nr. 8-1998. 17 pp. (In Norwegian).

Bottrell HH. 1975. Generation time, length of life, instar duration and frequency of moulting, and their relationship to temperature in eight species of Cladocera from the River Thames, Reading. Oecologia 19: 129-140. doi: 10.1007/BF00369097

Dahl K. 1913. Laks og ørret. Fiskeri og kultur. Håndbok for fiskere, jordbrukere og skogsfolk. Nordisk forlag (Kristiania). 184 pp. (In Norwegian).

Dahl K. 1917. Ørret og ørretvann. Studier og forsøk (new edition in 1943). J.W.Cappelens forlag. 182 pp. (In Norwegian).

Dahl K. 1926. Undersøkelser ved Tunhøvdfjorden angaaende fiskens næringsforhold før og efter reguleringen. Meddelelser fra Norges Vassdrags- og Elektrisitetsvesen. Foss 1.18 pp. (In Norwegian).

Dahl K. 1930. A study on the supplies of fish food organisms in Norwegian lakes. Skrifter utgitt av Det Norske Videnskaps-Akademi i Oslo. I. Mat.-Naturv. Klasse. 1930. No. 1. 58 pp.

Dahl K. 1932. Influence of water storage of food conditions on trout in Lake Paalsbufjord. Skrifter utgitt av Det Norske Videnskaps-Akademi i Oslo. I. Mat.-Naturv. Klasse. 1931. No. 4. 53 pp.

Fjellheim A. 2004. Virkning av rotenonbehandling på bunndyrsamfunnene i et område ved Stigstu, Hardangervidda. Lab. for Ferskvannsøkologi og Innlandsfiske, Bergen, Rapport nr. 122.60 pp. (In Norwegian).

Fjellheim A, Tysse Å, Bjerknes V, Wright RF. 2002. Finprikkauren på Hardangervidda. DN-utredning 2002-1. 58 pp. (In Norwegian).

Fjellheim A, Tysse Å, Bjerknes W. 2007. Fish Stomachs as a Biomonitoring Tool in Studies of Invertebrate Recovery. Water, Air and Soil Pollution 7: 293-300. doi: 10.1007/s11267-006-9074-X

Gillooly JF. 2000. Effect of body size and temperature on generation time in zooplankton. Journal of Plankton Research 22 (2): 241-251. doi: 10.1093/plankt/22.2.241

Halvorsen G. 1973. Crustacea from the High Mountain Area Hardangervidda, South Norway. Reports from the High Mountain Ecology Research Station, Finse, Norway. University in Oslo. 1973:2. $17 \mathrm{pp}$.

Huitfeldt-Kaas H. 1911. Indberetning om Fiskeriforholdene paa Hardangervidden. I: Indstilling fra Fjeldbeitekomiteen om Harangviddens Utnyttelse. Landbruksdepartementet. (Centraltrykkeriet, Kristiania). 106 pp. (In Norwegian).

Jensen JW. 1975. Fisket $\mathrm{i}$ en del av elvene og vatnene som berøres av 
Eidfjord-Nord utbyggingen. Det Kongelige Norske Videnskabers Selskab, Museet, Universitetet i Trondheim. Rapport, Zoologisk serie 1975-15. 37 pp. (In Norwegian).

Koksvik JI. 1995. Seasonal occurrence and diel locomotor activity in littoral Cladocera in a mesohumic lake in Norway. Hydrobiologia 307: 193-201. doi: 10.1007/BF00032012

Madsen J-P. 1970. Fiskeriundersøkelser i Odda 1970. Låtevatn, Reinsnosvatn, Ljosavatn og Svartavatn. Hordaland landbruksselskap. Report. (In Norwegian).

Madsen J-P. 1971. Fiskeriundersøkelser i Eidfjord statsalmenning 1970. Hordaland landbruksselskap. Report. (In Norwegian).

Madsen J-P. 1980. Fiskeriundersøkelser for Kinso grunneigarlag 1980. Hordaland landbruksselskap. Report. (In Norwegian).

Myrvang R, Slettebø D. 2013. Historiske aurebestander (Salmo trutta) på Sentralvidda - Endringer i bestandsstruktur og livshistorietrekk som følge av endring i beskatning og variasjon i klimaforhold. Universitetet for miljø og biovitenskap, Institutt for naturforvaltning. MSc thesis. 66 pp. (In Norwegian).

Qvenild T. 1978. Fiskeribiologiske undersøkelser Uste - Nes, Hol kommune, 1976. Fiskerikonsulenten i Øst-Norge. Rapport. 44 pp. (In Norwegian).

Qvenild T, Rognerud S. 2018. Ørreten på Hardangervidda. Klimaets betydning for årsklassestyrke og produksjon av fisk og næringsdyr i Sandvatn 2001-2017. Norsk institutt for vannforskning (NIVA). Rapport LNR 7267-2018. 34 pp. (In Norwegian with an English summary). http://hdl.handle.net/11250/2495753

Qvenild T, Fjeld E, Fjellheim A, Rognerud S and Tysse Å. 2018. Climatic effects on a cold stenotherm species Lepidurus arcticus (Branchiopoda, Notostraca) on the southern outreach of its distribution range. Fauna norvegica 38: 37-53. doi: 10.5324/fn.v38i0.2598

Qvenild T, Hesthagen T. 2019. Environmental conditions limit the distribution of Lepidurus arcticus (Branchiopoda, Notostraca) on the Hardangervidda mountain plateau, Southern Norway. Fauna norvegica 39: 77-110. doi: 10.5324/fn.v39i0.2687

Qvenild T, Hesthagen T and Fjellheim A. 2020. The freshwater shrimp Gammarus lacustris (Malacostraca, Amphipoda) in lakes on the Hardangervidda mountain plateau, southern Norway: distribution and environmental requirements. Fauna norvegica 40: 1-21. doi: 10.5324/ fn.v40i0.3101

Rognerud S, Borgstrøm R, Qvenild T, Tysse A. 2003. Ørreten på Hardangervidda. Norsk institutt for vannforskning (NIVA). Rapport LNR 4712-2003. 68 pp. (In Norwegian). http://hdl.handle. net/11250/212189

Rognerud S, Qvenild T, Fjeld E. 2005. Hardangerviddaprosjektet. Resultater fra undersøkelsen i 2004. Norsk institutt for vannforskning (NIVA). Rapport LNR 5025-2005. 35 pp. (In Norwegian). http://hdl. handle.net/11250/212828

Rognerud S, Qvenild T, Rakhorst M, Rustadbakken A. 2006. Hardangerviddaprosjektet. Resultater fra undersøkelsen i 2005. Norsk institutt for vannforskning (NIVA). Rapport LNR 5181-2006. 35 pp. (In Norwegian). http://hdl.handle.net/11250/213144

Rognerud S, Fjeld E. 2014. Undersøkelser av fisk og næringsdyr i Mår og Ringedalsvatnet 2011-2013. Norsk institutt for vannforskning (NIVA). Rapport LNR 6682-2014. 52 pp. (In Norwegian). http://hdl.handle. net/11250/222905

Rukke NA. 2002. Effects of low calcium concentrations on two common freshwater crustaceans, Gammarus lacustris and Astacus astacus. Functional Ecology 16: 357-366. doi: 10.1046/j.1365-2435.2002.00637.x

Sandøy S, Nilssen JP. 1986. A geographical survey of littoral Crustacea in Norway and their use in paleolimnology. Hydrobiologia 143: 277-286. doi: 10.1007/BF00026671

Skjelkvåle BL, Henriksen A. 1998. Water chemistry, acidification status and critical loads for national parks; Hardangervidda. Norwegian Institute for Water Research, Report L.NO. 3895-98: 49 pp. (In Norwegian with an English summary). http://hdl.handle. net/11250/210017
Smirnov, NN. 1962. Eurycercus lamellatus (Chydoridae: Cladocera): field observations and nutrition. Hydrobiologia 20: 280-294. doi: 10.1007/BF00046194

Sømme ID. 1941. Ørretboka. Jacob Dybwads Forlag. Oslo (1941). 591 pp. (In Norwegian).

Tewson LH, Cowx IG, Nunn AD. 2016. Diel variation in the assemblage structure and foraging ecology of larval and $0+$ year juvenile fishes in a man-made floodplain waterbody. Journal of Fish Biology 88: 1486-1500. https://doi.org/10.1111/jfb.12924

Vasshaug Ø. 1970. Fiskeribiologiske undersøkelser 1967-69. Fiskerikonsulenten for Vest-Norge. Rapport. 67 pp. (In Norwegian).

Walseng B. 2015. Linsekreps Eurycercus lamellatus (A.F. Müller). Norwegian Biodiversity Information Centre, Trondheim. (In Norwegian). https://www.artsdatabanken.no/

Walseng B, Jensen TC. 2018. Crustacean communities in lakes with and without rudd (Scardinius erythrophthalmus), Arendal municipality Aust-Agder. Norsk institutt for naturforskning (NINA), Report 1599. $61 \mathrm{pp}$. (In Norwegian with an English summary).

Walseng B, Halvorsen G, Schartau AKL. 1994. Ferskvannsbiologiske undersøkelser i Kvenna, 1978. Norsk institutt for naturforskning (NINA), Oppdragsmelding nr. 321-1994. 33 pp. (In Norwegian).

Walseng B, Raddum G, Saksgård R, Schartau AKL. 1996. Ferskvannsbiologiske undersøkelser i Kvenna 1995, med fokus på indikatorarter som redskap i forsuringsovervåkingen. Norsk institutt for naturforskning (NINA), Oppdragsmelding nr. 433-1996. 36 pp. (In Norwegian).

Örnólfsdóttir EB, Einarsson A. 2004. Spatial and temporal variation of benthic cladocera (Crustacea) studied with activity traps in Lake Myvatn, Iceland. Aquatic Ecology, (2004) 38: 239-257. 10.1023/B:AECO.0000032059.99310.d3

Editorial responsibility: Torkild Bakken.

This article is open-access and distributed under the terms of the Creative Commons Attribution 4.0 International license. This permits all noncommercial use, distribution, and reproduction in any medium, provided the original work is properly cited.

(http://creativecommons.org/licenses/by/4.0/). 
Appendix I. Specific information of the 144 lakes examined in the 27 catchments with 11 catchments in the western region (W) and 16 catchments in the central and eastern region $(\mathrm{C} / \mathrm{E})$. The number of examinations is specified together with any associated positive records. Reg indicates that the lake is regulated. The numbered references are specified below the table.

\begin{tabular}{|c|c|c|c|c|c|c|c|c|c|c|c|c|c|c|}
\hline \multirow{2}{*}{ 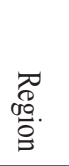 } & \multirow{2}{*}{ 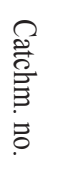 } & \multirow{2}{*}{ 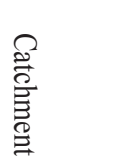 } & \multirow{2}{*}{ 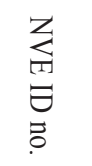 } & \multirow{2}{*}{ 氨 } & \multirow{2}{*}{ 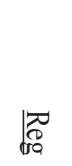 } & \multirow{2}{*}{ 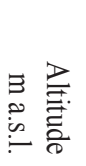 } & \multirow{2}{*}{ 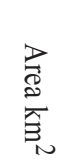 } & \multicolumn{2}{|c|}{ ESPG: 25833} & \multirow{2}{*}{ 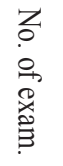 } & \multirow{2}{*}{$\begin{array}{l}\overrightarrow{0} \\
0 \\
\vec{\Phi} \\
\vec{\Gamma}\end{array}$} & \multirow[b]{2}{*}{ 焉 } & \multirow{2}{*}{ 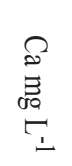 } & \multirow{2}{*}{ 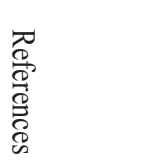 } \\
\hline & & & & & & & & $X$ & $\mathrm{Y}$ & & & & & \\
\hline W & 1 & Austdøla & 1917 & $\begin{array}{l}\text { Austdølnut- } \\
\text { vatnet }\end{array}$ & Reg & 1040 & 0.63 & 70590 & 6742742 & 2 & 0 & & & 28,74 \\
\hline W & 1 & Austdøla & 1918 & Rundavatnet & Reg & 1040 & 1.28 & 72020 & 6744428 & 2 & 0 & & & 28,74 \\
\hline W & 1 & Austdøla & 1921 & Langvatnet & Reg & 1158 & 6.40 & 69287 & 6739016 & 2 & 1 & 6.4 & 0.56 & $26,28,55,74$ \\
\hline W & 1 & Austdøla & 1922 & $\begin{array}{l}\text { Kvilinganut- } \\
\text { vatnet }\end{array}$ & & 1140 & 0.53 & 74117 & 6745937 & 1 & 0 & 5.8 & 0.4 & 28,74 \\
\hline W & 1 & Austdøla & 16656 & Austdalsvatnet & & 1059 & 0.08 & 72907 & 6743724 & 1 & 0 & & & 28 \\
\hline W & 1 & Austdøla & 16664 & Austdalsvatnet & & 1163 & 0.32 & 75886 & 6742930 & 1 & 0 & 6.9 & 1.2 & $26,28,74$ \\
\hline W & 1 & Austdøla & 16677 & Rossevatni & & 954 & 0.09 & 69545 & 6743018 & 1 & 0 & & & 28,74 \\
\hline W & 1 & Austdøla & 16682 & Rossevatni & & 936 & 0.06 & 68971 & 6743002 & 2 & 0 & & & 74 \\
\hline W & 1 & Austdøla & 16712 & Austdølvatnet & & 907 & 0.13 & 68552 & 6742080 & 2 & 0 & & & 28,74 \\
\hline W & 1 & Austdøla & 16787 & Grasbotntjørni & & 1107 & 0.12 & 68354 & 6740315 & 1 & 0 & & & 28 \\
\hline W & 2 & Sima & 17050 & $\begin{array}{l}\text { Skykkjedals- } \\
\text { vatnet }\end{array}$ & & 837 & 0.43 & 75584 & 6731638 & 2 & 2 & 6.65 & 1.48 & 38 \\
\hline $\mathrm{C} / \mathrm{E}$ & $3 \mathrm{~A}$ & Isdølo & 1906 & Isdalsvatnet & & 832 & 1.07 & 76533 & 6726176 & 2 & 2 & 6.52 & 2.12 & $28,34,74$ \\
\hline $\mathrm{C} / \mathrm{E}$ & $3 \mathrm{~B}$ & Leiro & 1907 & Sysenvatn & Reg & 880 & 10.42 & 82835 & 6722461 & 3 & 2 & 6.6 & 0.88 & $28,34,51,74$ \\
\hline $\mathrm{C} / \mathrm{E}$ & $3 \mathrm{~B}$ & Leiro & 17070 & Finsbergvatnet & & 1190 & 1.23 & 95280 & 6728945 & 1 & 0 & 6.02 & 0.82 & 13,55 \\
\hline $\mathrm{C} / \mathrm{E}$ & $3 \mathrm{~B}$ & Leiro & 17149 & Langavatnet & & 1124 & 0.74 & 91211 & 6726281 & 1 & 0 & 6.03 & 0.62 & 13 \\
\hline $\mathrm{C} / \mathrm{E}$ & $3 \mathrm{~B}$ & Leiro & 17289 & Halnetjørni & & 1259 & 0.16 & 96421 & 6722876 & 1 & 0 & & & 42 \\
\hline $\mathrm{C} / \mathrm{E}$ & $3 \mathrm{~B}$ & Leiro & 17291 & Dalboretjern & & 1153 & 0.12 & 92974 & 6723206 & 1 & 0 & 6.38 & 0.85 & 13,42 \\
\hline $\mathrm{C} / \mathrm{E}$ & $3 \mathrm{~B}$ & Leiro & 17305 & $\begin{array}{l}\text { Inste } \\
\text { Olavsbuvatn }\end{array}$ & & 1175 & 0.64 & 95206 & 6721531 & 1 & 0 & & & 42 \\
\hline $\mathrm{C} / \mathrm{E}$ & $3 \mathrm{~B}$ & Leiro & 17322 & Skardstjørnane & & 1125 & 0.29 & 91140 & 6721561 & 1 & 0 & 6.51 & 1.91 & 13,42 \\
\hline $\mathrm{C} / \mathrm{E}$ & $3 \mathrm{~B}$ & Leiro & 17402 & Dyratjørnane & & 1173 & 0.25 & 92219 & 6719647 & 1 & 0 & 5.93 & 0.75 & 13,42 \\
\hline $\mathrm{C} / \mathrm{E}$ & 4 & Bjoreio & 17865 & $\begin{array}{l}\text { Kleivshovd- } \\
\text { tjørnane }\end{array}$ & & 1215 & 0.82 & 89929 & 6701871 & 1 & 1 & & & 42,44 \\
\hline $\mathrm{C} / \mathrm{E}$ & 4 & Bjoreio & 27430 & Tinnhølen & & 1213 & 4.54 & 90972 & 6704204 & 2 & 2 & 7.05 & 4.16 & $12,13,55$ \\
\hline $\mathrm{C} / \mathrm{E}$ & 5 & Veig & 18409 & Grøndalsvatni & & 1268 & 0.56 & 63593 & 6693034 & 1 & 0 & & & $23,42,45$ \\
\hline $\mathrm{C} / \mathrm{E}$ & 5 & Veig & 18434 & Grøndalsvatni & & 1281 & 0.22 & 61784 & 6692865 & 1 & 0 & 7.15 & 3.08 & $23,42,45,55$ \\
\hline $\mathrm{C} / \mathrm{E}$ & $7 \mathrm{~A}$ & Kinso & 1912 & Veivatnet & & 1172 & 4.68 & 53384 & 6706672 & 1 & 0 & & 3.16 & 42,74 \\
\hline $\mathrm{C} / \mathrm{E}$ & $7 \mathrm{~A}$ & Kinso & 1913 & $\begin{array}{l}\text { Omkjelsvatnet } \\
\text { Nedre }\end{array}$ & & 1199 & 2.39 & 55086 & 6701409 & 1 & 0 & & 2.32 & 42,74 \\
\hline $\mathrm{C} / \mathrm{E}$ & $7 \mathrm{~A}$ & Kinso & 17878 & Kinsevatnet & & 1184 & 0.26 & 56181 & 6704912 & 1 & 0 & & 3.32 & 42,74 \\
\hline $\mathrm{C} / \mathrm{E}$ & $7 \mathrm{~A}$ & Kinso & 27476 & Rjuvavatnet & & 889 & 0.30 & 48598 & 6715537 & 1 & 0 & & 2.24 & 42,74 \\
\hline $\mathrm{C} / \mathrm{E}$ & $7 \mathrm{~A}$ & Kinso & 27478 & Stavalivatnet & & 900 & 0.69 & 49566 & 6715667 & 2 & 1 & & 2.12 & 42,74 \\
\hline $\mathrm{C} / \mathrm{E}$ & $7 \mathrm{~A}$ & Kinso & 27500 & Kinsevatnet & & 940 & 0.21 & 49818 & 6712693 & 1 & 1 & & & 42 \\
\hline $\mathrm{C} / \mathrm{E}$ & $7 \mathrm{~A}$ & Kinso & 27510 & $\begin{array}{l}\text { Fodnastøls- } \\
\text { vatnet }\end{array}$ & & 955 & 0.33 & 50687 & 6712409 & 1 & 1 & 7.22 & 3.89 & 42,55 \\
\hline $\mathrm{C} / \mathrm{E}$ & $7 \mathrm{~A}$ & Kinso & 27523 & $\begin{array}{l}\text { Austmanna- } \\
\text { vatnet }\end{array}$ & & 1170 & 0.19 & 54407 & 6710520 & 1 & 1 & & & 42 \\
\hline $\mathrm{C} / \mathrm{E}$ & $7 \mathrm{~A}$ & Kinso & 27573 & Sperrådalsvatn & & 1179 & 0.14 & 55531 & 6705279 & 1 & 0 & & 2.44 & 74 \\
\hline W & $7 \mathrm{~B}$ & Vivippo & 27450 & Grytingsvatn & & 700 & 0.24 & 48434 & 6721377 & 1 & 0 & & & 42 \\
\hline W & 8 & Opo & 1904 & Opesjovatnet & & 1014 & 1.25 & 44930 & 6712854 & 1 & 0 & 6.65 & 0.76 & $42,55,74$ \\
\hline W & $9 \mathrm{~A}$ & Espeelvi & 27611 & Mostjørn & & 1238 & 0.25 & 39059 & 6702750 & 1 & 0 & & & 47 \\
\hline W & $9 \mathrm{~B}$ & Vendo & 1903 & $\begin{array}{l}\text { Store } \\
\text { Vendevatnet }\end{array}$ & Reg & 1268 & 3.64 & 41667 & 6704733 & 2 & 0 & 6.8 & 1.28 & 34,36 \\
\hline
\end{tabular}


Appendix I. Continued.

\begin{tabular}{|c|c|c|c|c|c|c|c|c|c|c|c|c|c|c|}
\hline \multirow{2}{*}{ 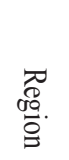 } & \multirow{2}{*}{ 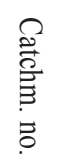 } & \multirow{2}{*}{ 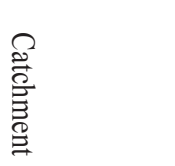 } & \multirow{2}{*}{$\begin{array}{l}\text { Z } \\
\text { T] } \\
\boxminus \\
\Xi \\
\Xi\end{array}$} & \multirow{2}{*}{$\stackrel{\leftarrow}{\hat{2}}$} & \multirow{2}{*}{ 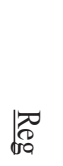 } & \multirow{2}{*}{ 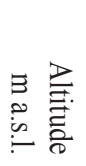 } & \multirow{2}{*}{ 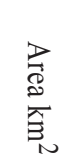 } & \multicolumn{2}{|c|}{ ESPG: 25833} & \multirow{2}{*}{ 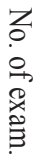 } & \multirow{2}{*}{$\begin{array}{l}\text { D } \\
0 \\
\overrightarrow{0} \\
\stackrel{8}{0}\end{array}$} & \multirow[b]{2}{*}{ 焉 } & \multirow{2}{*}{ 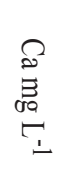 } & \multirow{2}{*}{ 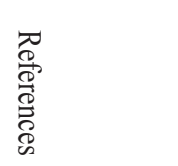 } \\
\hline & & & & & & & & $X$ & $\mathrm{Y}$ & & & & & \\
\hline W & 10 & Tysso & 1890 & Øvre Tyssevatn & Reg & 1333 & 2.92 & 49307 & 6698163 & 3 & 0 & 6.38 & 0.64 & $34,36,47$ \\
\hline W & 10 & Tysso & 1892 & Nonskardvatnet & & 1284 & 1.39 & 54087 & 6693281 & 2 & 0 & 6.67 & 0.95 & 47,55 \\
\hline W & 10 & Tysso & 1893 & $\begin{array}{l}\text { Øvre } \\
\text { Bersåvatnet }\end{array}$ & Reg & 1106 & 3.37 & 40547 & 6699937 & 3 & 0 & & & 34,47 \\
\hline W & 10 & Tysso & 1894 & Nibbehølen & Reg & 1191 & 2.06 & 46031 & 6690183 & 4 & 2 & 6.4 & 0.64 & $34,36,47$ \\
\hline W & 10 & Tysso & 1897 & $\begin{array}{l}\text { Øvre } \\
\text { Nybuvatnet }\end{array}$ & & 1191 & 0.68 & 50202 & 6690302 & 3 & 0 & & & 34,47 \\
\hline W & 10 & Tysso & 1898 & $\begin{array}{l}\text { Nedre } \\
\text { Håvardsvatnet }\end{array}$ & Reg & 1264 & 5.46 & 54458 & 6690703 & 5 & 0 & 6.67 & 1.03 & 36,47 \\
\hline W & 10 & Tysso & 1900 & $\begin{array}{l}\text { Nedre } \\
\text { Bersåvatnet }\end{array}$ & Reg & 1029 & 0.88 & 38299 & 6698844 & 3 & 0 & & & 34,47 \\
\hline W & 10 & Tysso & 1901 & Langevatnet & Reg & 1190 & 6.36 & 41622 & 6687621 & 5 & 1 & 6.28 & 0.53 & $34,35,36,47$ \\
\hline W & 10 & Tysso & 1902 & Breidavatn & Reg & 1232 & 3.35 & 47989 & 6685761 & 3 & 0 & & & 34,47 \\
\hline W & 10 & Tysso & 27650 & Nedre Tyssevatn & & 1317 & 0.43 & 48130 & 6697391 & 3 & 0 & & & 34,47 \\
\hline W & 10 & Tysso & 27661 & Hadletgrøna & & 1264 & 0.35 & 42541 & 6697205 & 1 & 0 & & & 47 \\
\hline W & 10 & Tysso & 27663 & Holmevatn & & 1271 & 0.84 & 45895 & 6696516 & 4 & 0 & 6.36 & 0.64 & $34,36,47$ \\
\hline W & 10 & Tysso & 27669 & $\begin{array}{l}\text { Nedre } \\
\text { Veidedalsvatn }\end{array}$ & & 1312 & 0.15 & 47503 & 6696107 & 1 & 0 & & & 47 \\
\hline W & 10 & Tysso & 27672 & Stednesvatnet & & 1213 & 0.15 & 44070 & 6695812 & 2 & 0 & & & 34,47 \\
\hline W & 10 & Tysso & 27677 & $\begin{array}{l}\text { Øvre } \\
\text { Veidedalsvatn }\end{array}$ & & 1333 & 0.22 & 49095 & 6694926 & 1 & 0 & & & 47 \\
\hline W & 10 & Tysso & 27680 & Tyssehølen & & 1162 & 0.11 & 43332 & 6695188 & 1 & 0 & & & 34 \\
\hline W & 10 & Tysso & 27682 & Reinakolltjørn & & 1359 & 0.18 & 45595 & 6694481 & 1 & 0 & & & 47 \\
\hline W & 10 & Tysso & 27693 & Langtjørn & & 1305 & 0.27 & 45054 & 6692759 & 1 & 0 & & & 47 \\
\hline W & 10 & Tysso & 27758 & $\begin{array}{l}\text { Hattasteins- } \\
\text { vatnet }\end{array}$ & & 1287 & 0.92 & 47553 & 6683669 & 1 & 0 & & & 47 \\
\hline W & 11 & $\begin{array}{l}\text { Austdølo/ } \\
\text { Kjølo }\end{array}$ & 1702 & Reinsnosvatnet & & 594 & 3.35 & 36722 & 6675691 & 1 & 1 & & & 42 \\
\hline W & 11 & $\begin{array}{l}\text { Austdølo/ } \\
\text { Kjølo }\end{array}$ & 23143 & Ljosevatn & & 630 & 0.57 & 38106 & 6678046 & 1 & 1 & & & 42 \\
\hline W & 12 & Suldalsvassd & 1866 & Valldalsvatnet & Reg & 745 & 7.33 & 50628 & 6672273 & 2 & 2 & 6.33 & 0.63 & 34,37 \\
\hline W & 13 & Bora & 55 & Bordalsvatnet & Reg & 891 & 7.69 & 70888 & 6656673 & 3 & 2 & 6.5 & 2.62 & $\begin{array}{l}11,25,41, \\
43,60\end{array}$ \\
\hline W & 13 & Bora & 12118 & Åremotvatni & Reg & 1180 & 1.13 & 68743 & 6665138 & 1 & 1 & 5.9 & 0.9 & $25,56,61$ \\
\hline $\mathrm{C} / \mathrm{E}$ & 14 & Songa & 10 & Songa & Reg & 974 & 30.01 & 82524 & 6659180 & 6 & 6 & 6.4 & 0.97 & $\begin{array}{l}1,11,25,59 \\
62,65\end{array}$ \\
\hline $\mathrm{C} / \mathrm{E}$ & 15 & Kvenna & 12 & Vollevatnet & & 1030 & 1.66 & 94853 & 6676114 & 4 & 2 & 6.2 & 1.33 & $\begin{array}{l}30,51,56 \\
\text { own data }\end{array}$ \\
\hline $\mathrm{C} / \mathrm{E}$ & 15 & Kvenna & 13 & Briskevatnet & & 1068 & 2.62 & 89550 & 6677403 & 3 & 2 & 6.6 & 3.74 & $\begin{array}{l}25,30, \text { own } \\
\text { data }\end{array}$ \\
\hline $\mathrm{C} / \mathrm{E}$ & 15 & Kvenna & 14 & $\begin{array}{l}\text { Gunleiksbu- } \\
\text { vatnet }\end{array}$ & & 1071 & 1.29 & 85362 & 6678032 & 5 & 5 & 6.62 & 1.59 & $\begin{array}{l}30,51,55,75, \\
76, \text { own data }\end{array}$ \\
\hline $\mathrm{C} / \mathrm{E}$ & 15 & Kvenna & 15 & $\begin{array}{l}\text { Nedre } \\
\text { Bjørnavatnet }\end{array}$ & & 1136 & 2.13 & 75023 & 6679965 & 1 & 0 & 6.7 & 2.13 & $\begin{array}{l}33,45,55 \\
75,76\end{array}$ \\
\hline $\mathrm{C} / \mathrm{E}$ & 15 & Kvenna & 16 & $\begin{array}{l}\text { Øvre } \\
\text { Bjørnavatnet }\end{array}$ & & 1147 & 2.92 & 71335 & 6679440 & 4 & 3 & 6.53 & 1.46 & $\begin{array}{l}32,33,45,55, \\
75,76\end{array}$ \\
\hline $\mathrm{C} / \mathrm{E}$ & 15 & Kvenna & 17 & Sandvatn & & 1112 & 1.57 & 82122 & 6681359 & 15 & 15 & 6.4 & 1.15 & $\begin{array}{l}25,30 \text {, own } \\
\text { data }\end{array}$ \\
\hline $\mathrm{C} / \mathrm{E}$ & 15 & Kvenna & 18 & $\begin{array}{l}\text { Nedre } \\
\text { Krokavatn }\end{array}$ & & 1141 & 1.16 & 77610 & 6684108 & 1 & 1 & 6.7 & 2.73 & 32,75 \\
\hline
\end{tabular}


Appendix I. Continued.

\begin{tabular}{|c|c|c|c|c|c|c|c|c|c|c|c|c|c|c|}
\hline \multirow{2}{*}{ 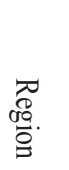 } & \multirow{2}{*}{ 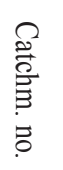 } & \multirow{2}{*}{ 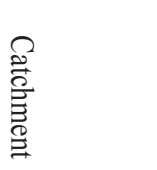 } & \multirow{2}{*}{ 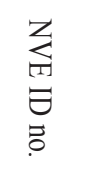 } & \multirow{2}{*}{$\underset{\overrightarrow{0}}{\overrightarrow{0}}$} & \multirow{2}{*}{ 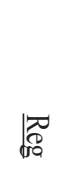 } & \multirow{2}{*}{ 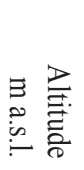 } & \multirow{2}{*}{ 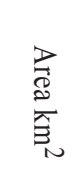 } & \multicolumn{2}{|c|}{ ESPG: 25833} & \multirow{2}{*}{ 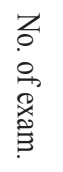 } & \multirow{2}{*}{$\begin{array}{l}\overparen{0} \\
: \\
\overrightarrow{0} \\
?\end{array}$} & \multirow[b]{2}{*}{ 诖 } & \multirow{2}{*}{ 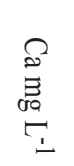 } & \multirow{2}{*}{ 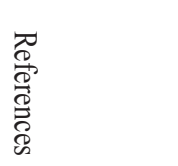 } \\
\hline & & & & & & & & $\mathrm{X}$ & $\mathrm{Y}$ & & & & & \\
\hline $\mathrm{C} / \mathrm{E}$ & 15 & Kvenna & 38 & Skardvatnet & & 1149 & 0.97 & 93901 & 6682778 & 1 & 1 & & & 31 \\
\hline $\mathrm{C} / \mathrm{E}$ & 15 & Kvenna & 39 & Fjellsjåen & & 1195 & 2.31 & 90148 & 6684863 & 7 & 5 & 6.31 & 0.74 & $\begin{array}{l}25,31,55,75, \\
76, \text { own data }\end{array}$ \\
\hline $\mathrm{C} / \mathrm{E}$ & 15 & Kvenna & 40 & Urdevatnet & & 1329 & 1.55 & 93521 & 6669198 & 3 & 3 & 5.81 & 0.44 & $\begin{array}{l}55,56,64 \\
75,76\end{array}$ \\
\hline $\mathrm{C} / \mathrm{E}$ & 15 & Kvenna & 42 & Valgardsvatni & & 1319 & 1.84 & 74012 & 6688631 & 3 & 3 & 6.36 & 1.42 & $\begin{array}{l}42,45,55,63 \\
75,76\end{array}$ \\
\hline $\mathrm{C} / \mathrm{E}$ & 15 & Kvenna & 43 & Litlosvatnet & & 1170 & 1.52 & 63673 & 6686656 & 7 & 4 & 6.56 & 1.19 & $\begin{array}{l}23,32,45 \\
54,55,75,76\end{array}$ \\
\hline $\mathrm{C} / \mathrm{E}$ & 15 & Kvenna & 11836 & $\begin{array}{l}\text { Vesle } \\
\text { Meinsvatnet }\end{array}$ & & 1353 & 0.57 & 96007 & 6670387 & 2 & 2 & 6.05 & 0.46 & 75,76 \\
\hline $\mathrm{C} / \mathrm{E}$ & 15 & Kvenna & 18495 & Grottjørnanene & & 1322 & 0.44 & 71055 & 6690732 & 1 & 0 & 6.6 & 3.46 & 75 \\
\hline $\mathrm{C} / \mathrm{E}$ & 15 & Kvenna & 18545 & Sledalsvatnet & & 1288 & 0.43 & 58269 & 6691313 & 1 & 0 & & & 33 \\
\hline $\mathrm{C} / \mathrm{E}$ & 15 & Kvenna & 18558 & Krokavatnet & & 1236 & 0.42 & 60847 & 6691012 & 3 & 1 & 6.8 & 2.57 & $33,45,57,75$ \\
\hline $\mathrm{C} / \mathrm{E}$ & 15 & Kvenna & 18581 & Ambjørsvatnet & & 1269 & 0.81 & 66343 & 6689682 & 2 & 0 & 6.6 & 2.33 & $9,23,45,55$ \\
\hline $\mathrm{C} / \mathrm{E}$ & 15 & Kvenna & 18597 & Skavatn & & 1249 & 0.47 & 64063 & 6690187 & 4 & 1 & 6.7 & 5.04 & $\begin{array}{l}23,24,33 \\
45,75\end{array}$ \\
\hline $\mathrm{C} / \mathrm{E}$ & 15 & Kvenna & 18700 & Kollsvatnet & & 1182 & 0.61 & 61644 & 6688435 & 9 & 6 & 6.7 & 1.5 & $\begin{array}{l}23,24,33,45 \\
49,55,57\end{array}$ \\
\hline $\mathrm{C} / \mathrm{E}$ & 15 & Kvenna & 18770 & Blånuttjørnane & & 1310 & 0.31 & 83830 & 6685129 & 1 & 1 & 6.72 & 2.3 & 55 , own data \\
\hline $\mathrm{C} / \mathrm{E}$ & 15 & Kvenna & 18773 & Krokavatni & & 1150 & 1.21 & 72085 & 6684881 & 1 & 1 & & & 32,42 \\
\hline $\mathrm{C} / \mathrm{E}$ & 15 & Kvenna & 18782 & Vassdalsvatni & & 1282 & 0.45 & 61466 & 6686400 & 2 & 0 & 6.26 & 1.25 & $23,33,55$ \\
\hline $\mathrm{C} / \mathrm{E}$ & 15 & Kvenna & 18827 & Dargesjåen & & 1205 & 0.64 & 87775 & 6683553 & 8 & 7 & 6 & 0.67 & $\begin{array}{l}25,31,63,64, \\
75,76, \text { own } \\
\text { data }\end{array}$ \\
\hline $\mathrm{C} / \mathrm{E}$ & 15 & Kvenna & 18831 & Vassdalsvatni & & 1299 & 0.74 & 59870 & 6685608 & 1 & 0 & & & 33 \\
\hline $\mathrm{C} / \mathrm{E}$ & 15 & Kvenna & 18854 & Kringlesjåen & & 1255 & 0.72 & 89249 & 6682690 & 5 & 2 & 6.1 & 0.64 & $\begin{array}{l}25,31,55,75 \\
76, \text { own data }\end{array}$ \\
\hline $\mathrm{C} / \mathrm{E}$ & 15 & Kvenna & 18919 & Tuevatni & & 1282 & 0.36 & 69955 & 6682678 & 1 & 1 & & & 45 \\
\hline $\mathrm{C} / \mathrm{E}$ & 15 & Kvenna & 19079 & Honserudvatnet & & 1045 & 0.38 & 93458 & 6676917 & 2 & 1 & & & Own data \\
\hline $\mathrm{C} / \mathrm{E}$ & 15 & Kvenna & 66946 & $\begin{array}{l}\text { Midtre } \\
\text { Krokavatn }\end{array}$ & & 1141 & 0.93 & 74249 & 6684438 & 1 & 1 & & & 32,42 \\
\hline $\mathrm{C} / \mathrm{E}$ & 16 & Møsvatn & 12178 & Landsetvatnet & & 1077 & 0.22 & 140859 & 6658142 & 1 & 1 & & & 7 \\
\hline $\mathrm{C} / \mathrm{E}$ & 16 & Møsvatn & 12188 & Middøltjønne & & 1072 & 0.06 & 141341 & 6658117 & 1 & 1 & & & 7 \\
\hline $\mathrm{C} / \mathrm{E}$ & 17 & Mår/ Gøyst & 36 & Mår & Reg & 1121 & 20.55 & 123922 & 6685973 & 3 & 3 & 6.2 & 1.02 & $\begin{array}{l}1,25,29,51, \\
52, \text { own data }\end{array}$ \\
\hline $\mathrm{C} / \mathrm{E}$ & 17 & Mår/ Gøyst & 75 & Gøystvatnet & Reg & 1087 & 31.26 & 123821 & 6676361 & 2 & 2 & 5.6 & 0.67 & $\begin{array}{l}11,25,29,51 \text {, } \\
\text { own data }\end{array}$ \\
\hline $\mathrm{C} / \mathrm{E}$ & 17 & Mår/ Gøyst & 92 & Rosjå & & 1174 & 2.03 & 134023 & 6680450 & 1 & 1 & 6.6 & 3.16 & 7,25 \\
\hline $\mathrm{C} / \mathrm{E}$ & 17 & Mår/ Gøyst & 107 & Store Saure & & 1120 & 1.63 & 115955 & 6674870 & 2 & 2 & 5.8 & 0.79 & 25,39 \\
\hline $\mathrm{C} / \mathrm{E}$ & 17 & Mår/ Gøyst & 109 & Viuvatnet & & 1324 & 3.03 & 109773 & 6687654 & 1 & 1 & 5.88 & 0.47 & $25,55,56,63$ \\
\hline $\mathrm{C} / \mathrm{E}$ & 17 & Mår/ Gøyst & 18721 & Ljostjørn & & 1178 & 0.42 & 134529 & 6681268 & 1 & 0 & & & 7 \\
\hline $\mathrm{C} / \mathrm{E}$ & $18 \mathrm{~A}$ & Uvdalselvi & 427 & $\begin{array}{l}\text { Store } \\
\text { Ormetjørni }\end{array}$ & & 1187 & 0.71 & 130989 & 6709879 & 3 & 3 & & & 21,22 \\
\hline $\mathrm{C} / \mathrm{E}$ & 18B & Uvdalselvi & 409 & Vikvatn & & 1064 & 1.22 & 133668 & 6694102 & 1 & 1 & 6.8 & 2 & 68 \\
\hline $\mathrm{C} / \mathrm{E}$ & $18 \mathrm{~B}$ & Uvdalselvi & 426 & Damtjørn & & 1223 & 0.44 & 143460 & 6698024 & 1 & 1 & & & 68 \\
\hline $\mathrm{C} / \mathrm{E}$ & $18 \mathrm{~B}$ & Uvdalselvi & 17949 & Sønstevatnet & Reg & 1060 & 12.53 & 142350 & 6693775 & 3 & 3 & 6.85 & 1.7 & 65,68 \\
\hline $\mathrm{C} / \mathrm{E}$ & $19 \mathrm{~A}$ & Lågen & 390 & Orsjoren & & 951 & 2.37 & 125791 & 6712627 & 2 & 0 & 6.8 & 1.5 & $2,12,67$ \\
\hline
\end{tabular}


Appendix I. Continued.

\begin{tabular}{|c|c|c|c|c|c|c|c|c|c|c|c|c|c|c|}
\hline \multirow{2}{*}{ 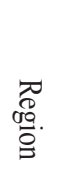 } & \multirow{2}{*}{ 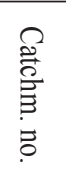 } & \multirow{2}{*}{ 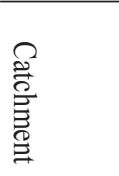 } & \multirow{2}{*}{$\begin{array}{l}z \\
\text { ZI } \\
\exists \\
\Xi \\
\Xi\end{array}$} & \multirow{2}{*}{$\stackrel{\overrightarrow{2}}{\overrightarrow{\hat{\sigma}}}$} & \multirow[b]{2}{*}{ 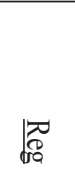 } & \multirow{2}{*}{ 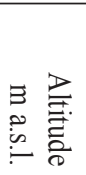 } & \multirow{2}{*}{ 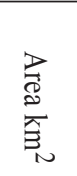 } & \multicolumn{2}{|c|}{ ESPG: 25833} & \multirow{2}{*}{ 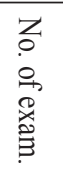 } & \multirow{2}{*}{ 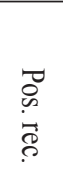 } & \multirow[b]{2}{*}{ 茥 } & \multirow{2}{*}{ 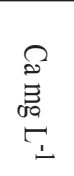 } & \multirow{2}{*}{ 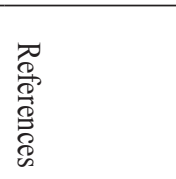 } \\
\hline & & & & & & & & $\mathrm{X}$ & $\mathrm{Y}$ & & & & & \\
\hline $\mathrm{C} / \mathrm{E}$ & $19 \mathrm{~A}$ & Lågen & 392 & Storekrekkja & & 1151 & 4.18 & 101435 & 6723196 & 3 & 3 & 5.91 & 0.7 & $63,64,69$ \\
\hline $\mathrm{C} / \mathrm{E}$ & $19 \mathrm{~A}$ & Lågen & 393 & Dragøyfjorden & & 1180 & 3.33 & 98419 & 6725710 & 3 & 2 & 5.49 & 0.65 & $17,51,69,72$ \\
\hline $\mathrm{C} / \mathrm{E}$ & $19 \mathrm{~A}$ & Lågen & 394 & Geitsjøen & & 1112 & 3.22 & 113050 & 6706544 & 4 & 3 & 6.9 & 1.32 & $2,12,74$ \\
\hline $\mathrm{C} / \mathrm{E}$ & $19 \mathrm{~A}$ & Lågen & 395 & Langesjøen & & 1210 & 11.04 & 97530 & 6698934 & 4 & 4 & 6.61 & 1.56 & $\begin{array}{l}4,12,46 \\
55,66\end{array}$ \\
\hline $\mathrm{C} / \mathrm{E}$ & $19 \mathrm{~A}$ & Lågen & 396 & Geitvatnet & & 1197 & 1.55 & 105307 & 6695177 & 1 & 1 & & & 14 \\
\hline $\mathrm{C} / \mathrm{E}$ & $19 \mathrm{~A}$ & Lågen & 414 & Øvre Hein & & 1113 & 6.33 & 106335 & 6714906 & 3 & 3 & 6.62 & 1.32 & $2,69,74$ \\
\hline $\mathrm{C} / \mathrm{E}$ & $19 \mathrm{~A}$ & Lågen & 415 & Halnefjorden & Reg & 1130 & 13.70 & 101185 & 6715697 & 8 & 8 & 6.3 & 1.76 & $\begin{array}{l}1,27,51 \\
69,74\end{array}$ \\
\hline $\mathrm{C} / \mathrm{E}$ & $19 \mathrm{~A}$ & Lågen & 416 & Langevatn & & 1158 & 5.09 & 116530 & 6700686 & 1 & 1 & & & 2,12 \\
\hline $\mathrm{C} / \mathrm{E}$ & $19 \mathrm{~A}$ & Lågen & 416 & Skrykken & & 1158 & 5.09 & 116530 & 6700686 & 1 & 1 & & & 2,12 \\
\hline $\mathrm{C} / \mathrm{E}$ & $19 \mathrm{~A}$ & Lågen & 418 & Bjornesfjorden & & 1223 & 18.38 & 93966 & 6692522 & 4 & 3 & 6.69 & 1.7 & $3,5,6,51,66$ \\
\hline $\mathrm{C} / \mathrm{E}$ & $19 \mathrm{~A}$ & Lågen & 420 & $\begin{array}{l}\text { Nordmanns- } \\
\text { lågen }\end{array}$ & & 1244 & 10.88 & 79991 & 6697139 & 1 & 1 & 6.87 & 2.4 & $13,42,44$ \\
\hline $\mathrm{C} / \mathrm{E}$ & $19 \mathrm{~A}$ & Lågen & 421 & $\begin{array}{l}\text { Dimmedals- } \\
\text { vatnet }\end{array}$ & & 1334 & 1.70 & 75845 & 6690862 & 1 & 0 & 5.9 & 2.53 & $13,45,75$ \\
\hline $\mathrm{C} / \mathrm{E}$ & $19 \mathrm{~A}$ & Lågen & 17018 & $\begin{array}{l}\text { Svartevass- } \\
\text { tjørni }\end{array}$ & & 1237 & 0.40 & 99168 & 6730136 & 6 & 5 & 5.74 & 0.28 & 17,71 \\
\hline $\mathrm{C} / \mathrm{E}$ & $19 \mathrm{~A}$ & Lågen & 17040 & Svartevatnet & & 1233 & 1.13 & 99538 & 6728768 & 10 & 7 & 5.69 & 0.35 & $17,42,71$ \\
\hline $\mathrm{C} / \mathrm{E}$ & $19 \mathrm{~A}$ & Lågen & 17366 & $\begin{array}{l}\text { Nedre } \\
\text { Bjørkevatn }\end{array}$ & & 1161 & 0.84 & 120435 & 6717924 & 3 & 0 & & & 2,51 \\
\hline $\mathrm{C} / \mathrm{E}$ & $19 \mathrm{~A}$ & Lågen & 17366 & Øvre Bjørkevatn & & 1161 & 0.84 & 120435 & 6717924 & 1 & 0 & & & 2,51 \\
\hline $\mathrm{C} / \mathrm{E}$ & $19 \mathrm{~A}$ & Lågen & 17397 & Heinumgen & & 1138 & 0.37 & 105066 & 6718724 & 2 & 2 & 6.34 & 0.83 & $2,69,74$ \\
\hline $\mathrm{C} / \mathrm{E}$ & $19 \mathrm{~A}$ & Lågen & 17411 & Hetjørni & & 1162 & 0.22 & 96712 & 6718971 & 1 & 0 & & & 42 \\
\hline $\mathrm{C} / \mathrm{E}$ & $19 \mathrm{~A}$ & Lågen & 17454 & Bjordalsvatn & & 1121 & 0.52 & 118134 & 6715599 & 1 & 1 & 7.15 & 4.04 & 2,55 \\
\hline $\mathrm{C} / \mathrm{E}$ & $19 \mathrm{~A}$ & Lågen & 17460 & Orsjøtjørni & & 1079 & 0.43 & 122190 & 6714827 & 1 & 0 & & & 2 \\
\hline $\mathrm{C} / \mathrm{E}$ & $19 \mathrm{~A}$ & Lågen & 17583 & Nedre Hein & & 1075 & 1.23 & 113349 & 6710330 & 4 & 4 & 6.6 & 1.48 & $2,27,69,74$ \\
\hline $\mathrm{C} / \mathrm{E}$ & $19 \mathrm{~A}$ & Lågen & 17591 & Halstjørni & & 1022 & 0.08 & 119782 & 6710045 & 1 & 1 & & & 2 \\
\hline $\mathrm{C} / \mathrm{E}$ & $19 \mathrm{~A}$ & Lågen & 17612 & Vesle Selstjørni & & 1128 & 0.10 & 109866 & 6710191 & 1 & 1 & & & 2 \\
\hline $\mathrm{C} / \mathrm{E}$ & $19 \mathrm{~A}$ & Lågen & 17617 & Store Selstjørni & & 1135 & 0.49 & 107988 & 6709350 & 2 & 2 & 7.19 & 2.44 & $2,55,74$ \\
\hline $\mathrm{C} / \mathrm{E}$ & $19 \mathrm{~A}$ & Lågen & 17898 & Nordvatnet & & 1256 & 1.02 & 78918 & 6701916 & 1 & 1 & 6.52 & 3.3 & $13,42,44,55$ \\
\hline $\mathrm{C} / \mathrm{E}$ & $19 \mathrm{~A}$ & Lågen & 17908 & Langesjøtjørni & & 1209 & 0.26 & 105566 & 6699604 & 1 & 0 & & & 46 \\
\hline $\mathrm{C} / \mathrm{E}$ & $19 \mathrm{~A}$ & Lågen & 18289 & X-tjørn & & 1326 & 0.04 & 75897 & 6694381 & 1 & 1 & & & 44 \\
\hline $\mathrm{C} / \mathrm{E}$ & $19 \mathrm{~A}$ & Lågen & 18305 & Y-tjørn & & 1330 & 0.04 & 75917 & 6693986 & 1 & 1 & & & 44 \\
\hline $\mathrm{C} / \mathrm{E}$ & $19 \mathrm{~A}$ & Lågen & 18374 & Bismarvatnet & & 1331 & 1.88 & 74729 & 6692150 & 1 & 0 & 6 & & $13,42,45$ \\
\hline $\mathrm{C} / \mathrm{E}$ & $19 \mathrm{~A}$ & Lågen & 66935 & Heintjønne & & 1112 & 0.58 & 109162 & 6712787 & 1 & 1 & 6.6 & 0.8 & 2,74 \\
\hline $\mathrm{C} / \mathrm{E}$ & $19 \mathrm{~A}$ & Lågen & 66954 & Hølen & & 1157 & 0.47 & 113891 & 6703571 & 1 & 1 & & & 12 \\
\hline $\mathrm{C} / \mathrm{E}$ & 19B & Ufysja & 17281 & Holværvatnet & & 1183 & 1.43 & 119750 & 6720539 & 2 & 1 & & & 2,12 \\
\hline $\mathrm{C} / \mathrm{E}$ & 19B & Ufysja & 17297 & Svantjern & & 1129 & 0.21 & 124886 & 6719724 & 1 & 0 & & & 2 \\
\hline $\mathrm{C} / \mathrm{E}$ & 19B & Ufysja & 17401 & Ljosevatnet & & 1182 & 0.90 & 125104 & 6716355 & 2 & 0 & & & 2 \\
\hline $\mathrm{C} / \mathrm{E}$ & 20 & Ørteråni & 553 & Ørteren & Reg & 1147 & 9.44 & 103584 & 6725146 & 3 & 2 & 6.48 & 1.1 & $15,16,50$ \\
\hline $\mathrm{C} / \mathrm{E}$ & 20 & Ørteråni & 17104 & Øvre Trestiklan & Reg & 1149 & 0.48 & 103408 & 6727693 & 2 & 1 & 6.43 & 0.7 & $15,16,50$ \\
\hline $\mathrm{C} / \mathrm{E}$ & 20 & Ørteråni & 17371 & Skjerjavatnet & & 1192 & 1.57 & 113282 & 6718885 & 2 & 1 & & & $\begin{array}{l}\text { 51, 58, own } \\
\text { data }\end{array}$ \\
\hline $\mathrm{C} / \mathrm{E}$ & 20 & Ørteråni & 67975 & Lægreidvatnet & Reg & 1147 & 1.74 & 106124 & 6723166 & 3 & 3 & 6.77 & 2.3 & $15,16,50$ \\
\hline
\end{tabular}




\section{REFERENCES}

References to vital statistics of the 144 lakes examined:

1 Aass P. 1969. Crustacea, especially Lepidurus arcticus Pallas, as brown trout food in Norwegian mountain reservoirs. Institute of Freshwater Research, Drottningholm. Report No 49, 1969: 183-201.

2 Amundsen T. 1976. Fiskeribiologiske undersøkelser for Dagalivassdraget 1974-75. Fiskerikonsulenten for Øst-Norge. Rapport Na IV-3.2. 285 pp. (In Norwegian).

3 Barlaup BT, Gabrielsen S-E, Skoglund H, Wiers T, Halvorsen GA, Hobæk A, Lehman GB, Pulg U, Skår B, Normann E, Fjellheim A. 2014. Bjornesfjorden - Restaurering av gyteområder og fiskeribiologiske undersøkelser i perioden 1999-2013. LFI Uni Research Miljø, LFI Rapport nr. 235. 60 pp. (In Norwegian).

4 Barlaup BT, Kleiven E, Skoglund H. 2002. Fiskebiologiske undersøkelser i Langesjøen, august 2001. Laboratoriet for ferskvannsøkologi og innlandsfiske (LFI), Universitetet i Bergen. Rapport nr. 120-2002. 39 pp. (In Norwegian).

5 Barlaup BT, Kleiven E, Raddum GG, Gabrielsen S-E, Johannessen A. 2000. Fiskebiologiske undersøkelser i Bjornesfjorden, august 1999. Laboratoriet for ferskvannsøkologi og innlandsfiske (LFI). Universitetet i Bergen. Rapport nr. 111-2000. 45 pp. (In Norwegian).

6 Barlaup BT, Sandven OR, Skoglund H, Gabrielsen S-E, Wiers T, Kleiven E, Lehmann G, Fjellheim A, Halvorsen GA, Hobæk A, Tysse A. 2008. Restaurering av gyteområder og prøvefiske i Bjornesfjorden 1999-2007. Laboratoriet for ferskvannsøkologi og innlandsfiske (LFI), Universitetet i Bergen. Rapport nr. 150-2008. 70 pp. (In Norwegian).

7 Bjørtuft SK, Saltveit SJ. 1993. Fiskeribiologiske undersøkelser i forbindelse med planlagte overføringer til Mår kraftverk i Telemark. Laboratoriet for ferskvannsøkologi og innlandsfiske (LFI), Universitetet i Oslo. Rapport nr. 140-1993. 33 pp. (In Norwegian).

8 Borgstrøm R, Brabrand Å, Solheim JT. 1986. Tilslamming og redusert siktedyp i Ringedalsmagasinet: Virkning på habitatbruk, næringsopptak og kondisjon hos pelagisk aure. Laboratoriet for ferskvannsøkologi og innlandsfiske (LFI), Universitetet i Oslo. Rapport nr. 90-1986. 36 pp. (In Norwegian).

9 Borgstrøm R, Sporan NR. 1998. Prøvefiske i Ambjørnsvatn, Ullensvang Statsallmenning, i 1997. Bestandsanalyse og forslag til driftsplan. Norges landbrukshøgskole, Institutt for biologi og naturforvaltning. Fiskerapport nr. 8-1998. 17 pp. (In Norwegian).

10 Borgstrøm R. 2014. Aurebestandane i Litlosvatn og Kollsvatn i Kvennavassdraget på Hardangervidda. Norges miljø- og biovitenskapelige universitet, Institutt for naturforvaltning. INA fagrapport 28. 24 pp. (In Norwegian).

11 Brabrand, Å. 2007. Virkning av lav sommervannstand på fisk i reguleringsmagasiner. Laboratorium for ferskvannsøkologi og innlandsfiske (LFI), Universitetet i Oslo. Rapport nr. 249-2007. 54 pp. (In Norwegian).

12 Dahl K. 1917. Studier og forsøk over Ørret og Ørretvand. Kristiania. Det Mallingske Bogtrykkeri. (In Norwegian).

13 Eidfjord fjellstyre 1995-2010. Diverse fiskerapporter. www.eidfjord-fjellstyre.no (In Norwegian).

14 Enerud J, Garnås E. 1987. Fiskeribiologiske undersøkelser i Geitvatnet, Nore og Uvdal kommune, Buskerud fylke. Fylkesmannen i Buskerud, miljøvernavdelingen. Rapport nr. F-1, 1987. 17 pp. (In Norwegian).

15 Enerud J, Garnås E. 1995. Fiskeribiologiske undersøkelser i Ørteren, Lægreidvatn, Øvre og Nedre Trestiklan, Hol kommune 1994. Fylkesmannen i Buskerud, miljøvernavdelingen. Rapport nr. 14-1995. 33 pp. (In Norwegian).

16 Enerud J. 2006. Fiskeribiologiske undersøkelser i Ørteren, Lægreidvatn, Øvre og Nedre Trestiklan, Hol kommune 2005. Fisk- og miljøundersøkelser. Rapport. 36 pp. (In Norwegian).

17 Fjellheim A, Tysse Å, Bjerknes V, Wright RF. 2002. Finprikkauren på Hardangervidda. DN-utredning 2002-1. 58 pp. (In Norwegian).

18 Fjellheim A, Tysse Å, Elnan G, Gåsdal O, Stakseng H. 2008. Finprikkauren på Hardangervidda. Statusrapport 2007. LFI-UNIFOB. Notat. 14 pp. (In Norwegian).

19 Fjellheim A, Tysse Å. 2011. Finprikkauren på Hardangervidda. Årsrapport 2010. LFI Uni Miljø. Notat. 15 pp. (In Norwegian).

20 Fjellheim A. 2004. Virkning av rotenonbehandling på bunndyrsamfunnene i et område ved Stigstu, Hardangervidda. Laboratoriet for ferskvannsøkologi og innlandsfiske (LFI-UNIFOB). Universitetet i Bergen. Rapport nr. 122. 60 pp.

21 Garnås E, Enerud J. 1996. Fiskeribiologiske undersøkelser i Ormetjern, Nore og Uvdal kommune, 1994. Fylkesmannen i Buskerud, miljøvernavdelingen. Rapport nr. 13-1996. 21 pp. (In Norwegian).

22 Garnås E, Huseby K. 1995. Prosjekt Fjellfisk. Et prosjekt for bedre utnyttelse av innlandsfiskeressurser. Sluttrapport 1986-1992. 34 pp. (In Norwegian).

23 Gjelsvik L. 1999. Størrelse og pigmentering hos Daphnia longispina i forhold til tettheten av ørret, Salmo trutta L., i innsjøer på Hardangervidda. Norges landbrukshøgskole, Institutt for biologi og naturforvaltning. MSc thesis. 49 pp. (In Norwegian).

24 Gjøstein G, Hauge TA. 1994. Vandring hjå allopatrisk aure, Salmo trutta L. i ulikt tette bestandar, eit radiotelemetristudium i tre vatn på Hardangervidda. Norges landbrukshøgskole, Institutt for biologi og naturforvaltning. MSc thesis. 32 pp. (In Norwegian).

25 Gulbrandsen TR, Johannessen M, Kildal T, Kjellsen A, Kulsvehagen E. 1986. Forsuringssituasjonen på Hardangervidda - kjemisk vannkvalitet og fiskestatus 1983-1985. Fylkesmannen i Telemark, miljøvernavdelingen. Rapport nr. 2/ 86. 35 pp. (In Norwegian).

26 Halvorsen G. 1973. Crustacea from the High Mountain Area Hardangervidda, South Norway. Rapport fra Høyfjellsøkologisk Forskningssenter, Finse, Norge. 1973 (3). 17 pp.

27 Hansen H, Garnås E. 1987. Fiskeribiologiske undersøkelser i Nedre Hein, Halnefjorden og Veslekrækkja, 1986. Fylkesmannen i Buskerud, miljøvernavdelingen. Rapport nr. 8-1987. 41 pp. (In Norwegian).

28 Jensen JW. 1975. Fisket i en del av elvene og vatnene som berøres av Eidfjord-Nord utbyggingen. Det Kongelige Norske Videnskabers Selskab, Museet, Universitetet i Trondheim. Rapport, Zoologisk serie 1975-15. 37 pp. (In Norwegian).

29 Kildal T, Johannessen M. 1983. Fiskeribiologiske undersøkingar i Mårvatn og Kalhovdmagasinet 1982. Fylkesmannen i Telemark, 
miljøvernavdelingen. Rapport nr. 1-1983. 34 pp. (In Norwegian).

30 Kildal T. 1980. Fiskeribiologiske undersøkelser i Kvenna 1978. Fiskerikonsulenten i Øst-Norge. Rapport. 41 pp. (In Norwegian).

31 Kildal T. 1981. Fiskeribiologiske undersøkelser i Skvettavassdraget 1980. Fiskerikonsulenten i Øst-Norge. Rapport nr. 17-1981. 33 pp. (In Norwegian).

32 Kildal T. 1982a. Fiskeribiologiske undersøkelser i Kvenna og Bjønna 1978. Fiskerikonsulenten i Øst-Norge. Rapport nr. 1-1982. 45 pp. (In Norwegian).

33 Kildal T. 1982b. Fiskeribiologiske undersøkelser i Kvenna 1979. Rapport frå brukerundersøkinga i Kvenna 1979. Fiskerikonsulenten i Øst-Norge. Rapport nr. 2-1982. 36 pp. (In Norwegian).

34 Lehmann GB, Wiers T. 2004. Fiskeressursprosjektet i Hordaland: Fiskeundersøkelser i regulerte innsjøer og vassdrag i Hordaland, juli 2002 april 2003. Fylkesmannen i Hordaland, miljøvernavdelingen. Rapport nr. 1-2004. 79 pp. (In Norwegian).

35 Lehmann GB, Wiers T. 2007. Prøvefiske i Langavatnet og Håvardsvatnet for AS Tyssefaldene, august 2006. LFI-Unifob. Rapport nr. $143-2007$. $34 \mathrm{pp}$. (In Norwegian).

36 Lehmann GB, Wiers T. 2011. Prøvefiske i magasiner i Tyssedalsfjellene for AS Tyssefaldene, august 2010. Undersøkelser av bestandsstatus for aure. LFI Uni Miljø. Rapport nr. 193-2011. 35 pp. (In Norwegian).

37 Lehmann GB, Wiers T. 2012. Fiskeundersøkelser i reguleringsmagasin i Røldal og Suldal, august 2011. LFI Uni Miljø. Rapport nr. 204-2012. 33 pp. (In Norwegian).

38 Lehmann GB. 2008. Fiskeribiologiske undersøkelser i Skytjedalsvatnet og Skytjedalselven, Eidfjord, september 2008. LFI-Unifob. Rapport nr. 154-2008. 19 pp. (In Norwegian).

39 Lunder K. 1973. Fiskeribiologiske undersøkelser i Store Saure. Fiskerikonsulenten i Øst-Norge. Rapport. 15 pp. (In Norwegian).

40 Løkensgard T, Rosseland L. 1963. Reguleringsoverføringer i Uvdalsvassdraget. Virkninger på fisket. Stensil.

41 Løkensgard T. 1958. Songavassdraget, de fiskeribiologiske forhold og den planlagte regulerings innvirkning på fiskeforholdene. Rapport VI, ekspropriasjonsskjønnet for Tokke-Vinjevassdraget. Bordalsvatnet og Margritsvatnet. 26. okt. 1958. 5 pp. (In Norwegian).

42 Madsen J-P. 1970-1988. Diverse fiskeriundersøkelser på Hardangervidda 1970-1988. Hordaland landbruksselskap/ Fylkesmannen i Hordaland. Diverse befaringsrapporter. (Oppbevares hos Fylkesmannen i Hordaland). (In Norwegian).

43 Meland A. 2008. Låg vasstand i Bordalsvatn sumaren 2006; innverknad på vekst og kvalitet hjå aure (Salmo trutta). Universitetet for miljø- og biovitenskap, Institutt for naturforvaltning. MSc thesis. 38 pp. (In Norwegian).

44 Muniz IP. 1968. Rapport fra de fiskeribiologiske undersøkelser i Odda og Ullensvang statsalmenninger sommeren 1967. Konsulenten for ferskvannsfisket i Vest-Norge. Rapport. 77 pp. (In Norwegian).

45 Muniz IP. 1969. Rapport fra de fiskeribiologiske undersøkelser i Eidfjord statsalmenning sommeren 1968. Konsulenten for ferskvannsfisket i Vest-Norge. Rapport. 72 pp. (In Norwegian).

46 Myrvang R, Slettebø D. 2013. Historiske aurebestander (Salmo trutta) på Sentralvidda - Endringer i bestandsstruktur og livshistorietrekk som følge av endring i beskatning og variasjon i klimaforhold. Universitetet for miljø og biovitenskap, Institutt for naturforvaltning. MSc thesis. 66 pp. (In Norwegian).

47 Nordland J. 1981. Fiskeribiologiske undersøkingar i A/S Tyssefaldene sitt reguleringsområde. Sommaren 1980. Fiskerikonsulenten i Vest-Norge. Rapport. 24 pp. (In Norwegian).

48 Norwegian Biodiversity Information Center, Artsdatabanken.no

49 Pedersen K, Scobie L. 1990. Dynamikk, habitatbruk og redskapsseleksjon for ørretbestanden i Kollsvatn, en innsjø på Hardangervidda. Norges landbrukshøgskole, Institutt for biologi og naturforvaltning. MSc thesis. 59 pp. (In Norwegian).

50 Qvenild T. 1978. Fiskeribiologiske undersøkelser Uste - Nes, Hol kommune, 1976. Fiskerikonsulenten i Øst-Norge. Rapport. 44 pp. (In Norwegian).

51 Rognerud S, Borgstrøm R, Qvenild T, Tysse Å. 2003. Ørreten på Hardangervidda. Norsk institutt for vannforskning (NIVA). Rapport LNR $4712-$ 2003. 68 pp. (In Norwegian).

52 Rognerud S, Fjeld E. 2014. Undersøkelser av fisk og næringsdyr i Mår og Ringedalsvatnet i forbindelse med en nedtapping og tilslamming i 2010-2013. Norsk institutt for vannforskning (NIVA). Rapport LNR 6682-2014. 52 pp. (In Norwegian).

53 Saltveit SJ, Brabrand Å. 2008. Fiskeribiologiske undersøkelser i Songa og Bitdalsvatn i 2007. Lab. for ferskvannsøkologi og innlandsfiske (LFI). Rapport nr. 263. 27 pp. (In Norwegian).

54 Simonsen TAA, Valderhaug NA. 1994. Bestandsdynamikk, habitatbruk og ernæring for aure i Litlosvatn - ein innsjø på Hardangervidda. Norges landbrukshøgskole, Institutt for biologi og naturforvaltning. MSc thesis. 65 pp. (In Norwegian).

55 Skjelkvåle BL, Henriksen A. 1998. Vannkjemi, forsuringsstatus og tålegrenser i nasjonalparker; Hardangervidda. NIVA Rapport LNR. 38951998. 48 pp. (In Norwegian).

56 Skogheim OK, Sevaldrud I, Henriksen A, Svalastog D, Hesthagen T. 1984. Vannkvalitet og fiskestatus i utvalgte områder på Hardangervidda i 1983. Direktoratet for naturforvaltning, fiskeforskningen. Rapport nr. 4-1984. 22 pp. (In Norwegian).

57 Slåttum M, Takvam L. 2006. Ørretbestanden (Salmo trutta) i Krokavatn, Ullensvang statsallmenning - én vellykket årsklasse kan gi overbefolkning. Universitetet for miljø og biovitenskap, Institutt for naturforvaltning. MSc thesis. 48 pp. (In Norwegian).

58 Smukkestad B. 1980. Rapport fra den fiskeribiologiske undersøkelse i Skjerja i Hol kommune 13. - 14. august 1979. Vilt- og fiskestellkonsulenten i Buskerud. Rapport. 12 pp. (In Norwegian).

59 Solhøi H. 1993. Rapport fra prøvefiske i Songa 1986 og 1992. Fylkesmannen i Telemark, miljøvernavdelingen. Rapport nr. 5-1993. 24 pp. (In Norwegian).

60 Solhøi H. 1997. Fiskeressurser i regulerte vassdrag i Telemark (Bordalsvatn). Fagrapport 1996. Fylkesmannen i Telemark, miljøvernavdelingen. 
Appendix I. Continued.

Rapport nr. 2-1997. 28 pp. (In Norwegian).

61 Solhøi H. 1999. Fiskeressurser i regulerte vassdrag i Telemark (Våmarvatn). Fagrapport 1998. Fylkesmannen i Telemark, miljøvernavdelingen. Rapport nr. 1-1999. 61 pp. (In Norwegian).

62 Solhøi H. 2003. Rapport fra prøvefiske. Samlerapport 2000-2003. Fiskeressurser i regulerte vassdrag i Telemark. Fylkesmannen i Telemark. miljøvernavdelingen. Rapport. (In Norwegian).

63 Statens forurensningstilsyn. 2001. Overvåking av langtransportert forurenset luft og nedbør. Årsrapport 2000. Statlig program for forurensningsovervåking. Rapport nr. 834-2001 (TA-1830-2001). (In Norwegian).

64 Statens forurensningstilsyn. 2006. Overvåking av langtransportert forurenset luft og nedbør. Årsrapport 2005. Statlig program for forurensningsovervåking. Rapport TA-2205-2006. (In Norwegian).

65 Tormodsgard L, Gustavsen PØ. 2013. Prøvefiske i Songavatn 2012. Naturpartner og Gustavsen Naturanalyser. Rapport GN 1-2013. 21 pp. (In Norwegian).

66 Tysse Å, Garnås E. 1990. Fiskeribiologisk undersøkjing i Langesjøen og Bjornesfjorden, Nore og Uvdal kommune 1989. Fylkesmannen i Buskerud, miljøvernavdelingen. Rapport nr. 11-1990, 48 pp. (In Norwegian).

67 Tysse Å, Garnås E. 1991. Fiskeribiologiske undersøkjingar i Ossjøen, Gvonnestøltjørni og Øvre Svangtjørn i Hol kommune 1990. Fylkesmannen i Buskerud, miljøvernavdelingen. Rapport nr. 12-1991. 38 pp. (In Norwegian).

68 Tysse Å, Garnås E. 1992. Fiskeribiologiske undersøkjingar i Sønstevatn, Damtjørn og Vikvatn i Nore og Uvdal kommune 1991. Fylkesmannen i Buskerud, miljøvernavdelingen. Rapport nr. 23-1992. 43 pp. (In Norwegian).

69 Tysse Å, Garnås E. 1994. Fiskeribiologiske undersøkjingar i Halne, Hein- og Krækkjavassdraget i Hol og Nore og Uvdal kommuner $1992 / 93$. Fylkesmannen i Buskerud, miljøvernavdelingen. Rapport nr. 16-1994. 33 pp. (In Norwegian).

70 Tysse Å, Garnås E. 1996. Kalking i Buskerud 1995-1998. Fylkesmannen i Buskerud, miljøvernavdelingen. Rapport nr. 11-1996. 35 pp. (In Norwegian).

71 Tysse A. 1996. Prikkauren i Svartavatnet og Svartavasstørni. Vasskvalitet, kalking og biologi. Notat. 29 pp. (In Norwegian).

72 Tysse Å. 2002. Undersøkjingar i Drageidfjorden 2002. Notat. 8 pp. (In Norwegian).

73 Vasshaug Ø, Waatevik E. 1976. A/S Tyssefallene - NVE og Statskraftverkene. Fiskeribiologiske reguleringsundersøkelser i Tyssovassdraget, Odda og Ullensvang kommuner. Fiskerikonsulenten i Vest-Norge, rapport. 20 pp. (In Norwegian).

74 Vasshaug Ø. 1970. Fiskeribiologiske undersøkelser 1967-69. Fiskerikonsulenten for Vest-Norge. Rapport. 67 pp. (In Norwegian).

75 Walseng B, Halvorsen G, Schartau AKL. 1994. Ferskvannsbiologiske undersøkelser i Kvenna, 1978. Norsk institutt for naturforskning (NINA), Oppdragsmelding nr. 321-1994. 33 pp. (In Norwegian).

76 Walseng B, Raddum G, Saksgård R, Schartau AKL. 1996. Ferskvannsbiologiske undersøkelser i Kvenna 1995, med fokus på indikatorarter som redskap i forsuringsovervåkingen. Norsk institutt for naturforskning (NINA), Oppdragsmelding nr. 433-1996. 36 pp. (In Norwegian). 
Appendix 2. The catch of brown trout and the crustacean species Eurycercus lamellatus, Gammarus lacustris and Lepidurus arcticus in the 100 fishing events in the five study lakes (cf. Qvenild et al. 2018).

\begin{tabular}{|c|c|c|c|c|c|c|c|c|c|c|}
\hline \multirow[b]{2}{*}{ Locality } & \multirow[b]{2}{*}{ Zone } & \multirow[b]{2}{*}{ Date } & \multicolumn{2}{|c|}{ No. of fish } & \multicolumn{2}{|c|}{$\begin{array}{l}\text { No. of fish with } \\
\text { E. lamellatus }\end{array}$} & \multicolumn{2}{|c|}{$\begin{array}{l}\text { No. of fish with } \\
\text { G. lacustris }\end{array}$} & \multicolumn{2}{|c|}{$\begin{array}{l}\text { No. of fish with } \\
\text { L. arcticus }\end{array}$} \\
\hline & & & $<25 \mathrm{~cm}$ & $\geq 25 \mathrm{~cm}$ & $<25 \mathrm{~cm}$ & $\geq 25 \mathrm{~cm}$ & $<25 \mathrm{~cm}$ & $\geq 25 \mathrm{~cm}$ & $<25 \mathrm{~cm}$ & $\geq 25 \mathrm{~cm}$ \\
\hline Blånuttjørnane & Littoral & 18.06 .04 & 10 & 9 & 4 & 0 & 4 & 8 & 0 & 0 \\
\hline Blånuttjørnane & Littoral & 17.08 .04 & 9 & 12 & 0 & 0 & 4 & 9 & 2 & 2 \\
\hline Dargesjåen & Littoral & 10.08 .03 & 37 & 32 & 2 & 2 & 10 & 3 & 16 & 12 \\
\hline Dargesjåen & Littoral & 13.08 .03 & 17 & 6 & 7 & 1 & 2 & 3 & 7 & 3 \\
\hline Dargesjåen & Littoral & 14.08 .03 & 0 & 25 & 0 & 1 & 0 & 14 & 0 & 14 \\
\hline Dargesjåen & Littoral & 17.06 .04 & 49 & 13 & 9 & 2 & 10 & 9 & 0 & 0 \\
\hline Dargesjåen & Littoral & 28.06 .07 & 36 & 25 & 0 & 0 & 5 & 6 & 0 & 0 \\
\hline Dargesjåen & Littoral & 29.09 .07 & 19 & 13 & 8 & 8 & 11 & 6 & 5 & 2 \\
\hline Dargesjåen & Littoral & 29.09 .11 & 0 & 12 & 0 & 9 & 0 & 1 & 0 & 4 \\
\hline Dargesjåen & Littoral & 28.09 .12 & 0 & 20 & 0 & 14 & 0 & 2 & 0 & 1 \\
\hline Fjellsjåen & Littoral & 02.10 .06 & 0 & 50 & 0 & 1 & 0 & 3 & 0 & 42 \\
\hline Fjellsjåen & Littoral & 27.06 .07 & 32 & 35 & 0 & 0 & 19 & 15 & 0 & 0 \\
\hline Fjellsjåen & Littoral & 29.09 .07 & 13 & 29 & 0 & 1 & 7 & 10 & 9 & 28 \\
\hline Fjellsjåen & Littoral & 27.09 .08 & 21 & 31 & 2 & 0 & 4 & 1 & 17 & 23 \\
\hline Fjellsjåen & Littoral & 21.06 .09 & 5 & 22 & 0 & 0 & 3 & 18 & 0 & 0 \\
\hline Fjellsjåen & Littoral & 02.10 .09 & 13 & 33 & 5 & 1 & 4 & 7 & 5 & 9 \\
\hline Fjellsjåen & Littoral & 26.06 .10 & 22 & 21 & 0 & 0 & 10 & 15 & 0 & 0 \\
\hline Fjellsjåen & Littoral & 29.09 .10 & 18 & 21 & 6 & 4 & 11 & 3 & 7 & 5 \\
\hline Fjellsjåen & Littoral & 29.09 .11 & 16 & 44 & 5 & 21 & 6 & 7 & 2 & 7 \\
\hline Fjellsjåen & Littoral & 28.09 .12 & 14 & 26 & 14 & 8 & 4 & 4 & 3 & 5 \\
\hline Gunleiksbuvatnet & Littoral & 13.08 .01 & 46 & 22 & 4 & 0 & 10 & 3 & 2 & 3 \\
\hline Sandvatn & Littoral & 12.08 .01 & 48 & 30 & 7 & 3 & 3 & 3 & 0 & 1 \\
\hline Sandvatn & Littoral & 14.08 .01 & 0 & 25 & 0 & 0 & 0 & 5 & 0 & 11 \\
\hline Sandvatn & Littoral & 12.08 .02 & 20 & 55 & 3 & 0 & 3 & 15 & 1 & 27 \\
\hline Sandvatn & Littoral & 16.08 .04 & 21 & 28 & 8 & 10 & 0 & 2 & 0 & 0 \\
\hline Sandvatn & Littoral & 15.08 .05 & 64 & 21 & 15 & 5 & 4 & 2 & 0 & 0 \\
\hline Sandvatn & Littoral & 16.08 .05 & 0 & 25 & 0 & 1 & 0 & 5 & 0 & 0 \\
\hline Sandvatn & Littoral & 17.08 .05 & 0 & 32 & 0 & 4 & 0 & 6 & 0 & 1 \\
\hline Sandvatn & Littoral & 19.08 .05 & 11 & 1 & 1 & 0 & 0 & 0 & 0 & 0 \\
\hline Sandvatn & Littoral & 14.08 .06 & 47 & 31 & 25 & 2 & 3 & 8 & 0 & 0 \\
\hline Sandvatn & Littoral & 16.08 .06 & 7 & 25 & 2 & 3 & 0 & 0 & 0 & 0 \\
\hline Sandvatn & Littoral & 27.06 .07 & 44 & 39 & 0 & 0 & 13 & 15 & 0 & 0 \\
\hline Sandvatn & Littoral & 12.08 .07 & 43 & 52 & 17 & 18 & 2 & 0 & 0 & 0 \\
\hline Sandvatn & Littoral & 13.08 .07 & 7 & 30 & 3 & 10 & 0 & 0 & 0 & 0 \\
\hline Sandvatn & Littoral & 14.08 .07 & 41 & 7 & 20 & 4 & 6 & 0 & 0 & 0 \\
\hline Sandvatn & Littoral & 15.08 .07 & 8 & 88 & 0 & 10 & 1 & 2 & 0 & 0 \\
\hline Sandvatn & Littoral & 30.09 .07 & 10 & 36 & 3 & 16 & 0 & 5 & 0 & 3 \\
\hline Sandvatn & Littoral & 10.08 .08 & 70 & 16 & 17 & 5 & 6 & 0 & 0 & 0 \\
\hline Sandvatn & Littoral & 11.08 .08 & 109 & 14 & 26 & 3 & 0 & 0 & 1 & 2 \\
\hline Sandvatn & Littoral & 13.08 .08 & 1 & 37 & 1 & 30 & 0 & 1 & 0 & 1 \\
\hline Sandvatn & Littoral & 14.08 .08 & 0 & 4 & 0 & 1 & 0 & 0 & 0 & 1 \\
\hline Sandvatn & Littoral & 15.08 .08 & 0 & 10 & 0 & 3 & 0 & 1 & 0 & 0 \\
\hline Sandvatn & Littoral & 16.08 .08 & 0 & 2 & 0 & 0 & 0 & 0 & 0 & 1 \\
\hline Sandvatn & Littoral & 28.09 .08 & 22 & 11 & 1 & 1 & 0 & 2 & 0 & 0 \\
\hline
\end{tabular}


Appendix 2. Continued.

\begin{tabular}{|c|c|c|c|c|c|c|c|c|c|c|}
\hline \multirow[b]{2}{*}{ Locality } & \multirow[b]{2}{*}{ Zone } & \multirow[b]{2}{*}{ Date } & \multicolumn{2}{|c|}{ No. of fish } & \multicolumn{2}{|c|}{$\begin{array}{l}\text { No. of fish with } \\
\text { E. lamellatus }\end{array}$} & \multicolumn{2}{|c|}{$\begin{array}{l}\text { No. of fish with } \\
\text { G. lacustris }\end{array}$} & \multicolumn{2}{|c|}{$\begin{array}{l}\text { No. of fish with } \\
\text { L. arcticus }\end{array}$} \\
\hline & & & $<25 \mathrm{~cm}$ & $\geq 25 \mathrm{~cm}$ & $<25 \mathrm{~cm}$ & $\geq 25 \mathrm{~cm}$ & $<25 \mathrm{~cm}$ & $\geq 25 \mathrm{~cm}$ & $<25 \mathrm{~cm}$ & $\geq 25 \mathrm{~cm}$ \\
\hline Sandvatn & Littoral & 09.08 .09 & 52 & 12 & 16 & 6 & 5 & 2 & 0 & 0 \\
\hline Sandvatn & Littoral & 10.08 .09 & 94 & 4 & 16 & 2 & 6 & 0 & 1 & 0 \\
\hline Sandvatn & Littoral & 12.08 .09 & 5 & 33 & 3 & 18 & 0 & 0 & 0 & 2 \\
\hline Sandvatn & Littoral & 14.08 .09 & 5 & 21 & 2 & 3 & 2 & 8 & 1 & 7 \\
\hline Sandvatn & Littoral & 26.06 .10 & 20 & 24 & 0 & 0 & 12 & 16 & 0 & 0 \\
\hline Sandvatn & Littoral & 08.08 .10 & 77 & 10 & 24 & 0 & 14 & 3 & 0 & 0 \\
\hline Sandvatn & Littoral & 09.08 .10 & 30 & 9 & 5 & 1 & 5 & 3 & 2 & 2 \\
\hline Sandvatn & Littoral & 10.08 .10 & 6 & 12 & 0 & 0 & 2 & 6 & 1 & 3 \\
\hline Sandvatn & Littoral & 11.08 .10 & 20 & 13 & 6 & 3 & 4 & 9 & 0 & 0 \\
\hline Sandvatn & Littoral & 30.09 .10 & 39 & 36 & 13 & 5 & 16 & 11 & 0 & 0 \\
\hline Sandvatn & Littoral & 14.08 .11 & 29 & 12 & 4 & 0 & 11 & 4 & 1 & 0 \\
\hline Sandvatn & Littoral & 15.08 .11 & 33 & 12 & 4 & 1 & 13 & 7 & 0 & 2 \\
\hline Sandvatn & Littoral & 16.08 .11 & 64 & 2 & 14 & 0 & 19 & 0 & 2 & 0 \\
\hline Sandvatn & Littoral & 18.08 .11 & 9 & 25 & 0 & 0 & 4 & 8 & 0 & 2 \\
\hline Sandvatn & Littoral & 19.08 .11 & 2 & 15 & 0 & 2 & 1 & 6 & 0 & 3 \\
\hline Sandvatn & Littoral & 30.09 .11 & 17 & 15 & 13 & 2 & 12 & 13 & 0 & 0 \\
\hline Sandvatn & Littoral & 13.08 .12 & 10 & 7 & 7 & 2 & 6 & 1 & 0 & 0 \\
\hline Sandvatn & Littoral & 14.08 .12 & 20 & 4 & 7 & 2 & 9 & 0 & 0 & 0 \\
\hline Sandvatn & Littoral & 15.08 .12 & 43 & 0 & 6 & 0 & 8 & 0 & 0 & 0 \\
\hline Sandvatn & Littoral & 16.08 .12 & 19 & 27 & 9 & 9 & 3 & 3 & 0 & 1 \\
\hline Sandvatn & Littoral & 17.08.12 & 0 & 15 & 0 & 1 & 0 & 2 & 0 & 5 \\
\hline Sandvatn & Littoral & 11.08 .13 & 33 & 5 & 12 & 0 & 11 & 1 & 2 & 0 \\
\hline Sandvatn & Littoral & 12.08 .13 & 18 & 19 & 6 & 3 & 6 & 7 & 1 & 3 \\
\hline Sandvatn & Littoral & 13.08 .13 & 42 & 10 & 15 & 1 & 12 & 6 & 3 & 1 \\
\hline Sandvatn & Littoral & 15.08 .13 & 82 & 5 & 48 & 0 & 16 & 2 & 9 & 2 \\
\hline Sandvatn & Littoral & 10.08 .14 & 66 & 14 & 7 & 0 & 28 & 7 & 7 & 2 \\
\hline Sandvatn & Littoral & 11.08 .14 & 28 & 6 & 5 & 0 & 9 & 4 & 5 & 1 \\
\hline Sandvatn & Littoral & 12.08 .14 & 4 & 5 & 0 & 0 & 2 & 4 & 0 & 0 \\
\hline Sandvatn & Littoral & 09.08 .15 & 58 & 16 & 1 & 1 & 29 & 3 & 0 & 0 \\
\hline Sandvatn & Littoral & 10.08 .15 & 21 & 31 & 0 & 0 & 10 & 13 & 0 & 0 \\
\hline Sandvatn & Littoral & 12.08 .15 & 4 & 59 & 1 & 2 & 0 & 12 & 0 & 0 \\
\hline Sandvatn & Littoral & 13.08 .15 & 29 & 0 & 0 & 0 & 7 & 0 & 0 & 0 \\
\hline Sandvatn & Littoral & 14.08 .15 & 5 & 37 & 0 & 0 & 2 & 5 & 0 & 0 \\
\hline Sandvatn & Littoral & 14.08 .16 & 45 & 19 & 19 & 3 & 5 & 8 & 1 & 4 \\
\hline Sandvatn & Littoral & 15.08 .16 & 52 & 17 & 12 & 5 & 11 & 8 & 3 & 1 \\
\hline Sandvatn & Littoral & 16.08 .16 & 19 & 0 & 4 & 0 & 1 & 0 & 0 & 0 \\
\hline Sandvatn & Littoral & 17.08.16 & 0 & 6 & 0 & 1 & 0 & 1 & 0 & 2 \\
\hline Sandvatn & Littoral & 18.08.16 & 36 & 29 & 12 & 3 & 3 & 2 & 3 & 3 \\
\hline Sandvatn & Profundal & 17.08 .01 & 8 & 3 & 1 & 1 & 0 & 0 & 0 & 1 \\
\hline Sandvatn & Profundal & 18.08 .04 & 1 & 41 & 0 & 0 & 0 & 11 & 0 & 1 \\
\hline Sandvatn & Profundal & 19.08 .04 & 20 & 0 & 5 & 0 & 3 & 0 & 0 & 0 \\
\hline Sandvatn & Profundal & 18.08 .05 & 1 & 21 & 0 & 1 & 0 & 4 & 0 & 7 \\
\hline Sandvatn & Profundal & 19.08 .05 & 1 & 6 & 0 & 0 & 0 & 2 & 0 & 3 \\
\hline Sandvatn & Profundal & 15.08 .06 & 12 & 10 & 3 & 0 & 2 & 2 & 0 & 1 \\
\hline Sandvatn & Profundal & 17.08 .06 & 0 & 2 & 0 & 1 & 0 & 0 & 0 & 0 \\
\hline Sandvatn & Profundal & 13.08 .07 & 12 & 0 & 12 & 0 & 1 & 0 & 0 & 0 \\
\hline
\end{tabular}


Appendix 2. Continued.

\begin{tabular}{|c|c|c|c|c|c|c|c|c|c|c|}
\hline \multirow[b]{2}{*}{ Locality } & \multirow[b]{2}{*}{ Zone } & \multirow[b]{2}{*}{ Date } & \multicolumn{2}{|c|}{ No. of fish } & \multicolumn{2}{|c|}{$\begin{array}{l}\text { No. of fish with } \\
\text { E. lamellatus }\end{array}$} & \multicolumn{2}{|c|}{$\begin{array}{l}\text { No. of fish with } \\
\text { G. lacustris }\end{array}$} & \multicolumn{2}{|c|}{$\begin{array}{l}\text { No. of fish with } \\
\text { L. arcticus }\end{array}$} \\
\hline & & & $<25 \mathrm{~cm}$ & $\geq 25 \mathrm{~cm}$ & $<25 \mathrm{~cm}$ & $\geq 25 \mathrm{~cm}$ & $<25 \mathrm{~cm}$ & $\geq 25 \mathrm{~cm}$ & $<25 \mathrm{~cm}$ & $\geq 25 \mathrm{~cm}$ \\
\hline Sandvatn & Profundal & 14.08 .07 & 29 & 11 & 18 & 8 & 2 & 2 & 0 & 0 \\
\hline Sandvatn & Profundal & 12.08 .08 & 60 & 18 & 17 & 5 & 3 & 3 & 2 & 5 \\
\hline Sandvatn & Profundal & 11.08 .09 & 51 & 5 & 9 & 0 & 7 & 4 & 2 & 3 \\
\hline Sandvatn & Profundal & 16.08 .11 & 4 & 22 & 0 & 3 & 1 & 8 & 0 & 3 \\
\hline Sandvatn & Profundal & 17.08.11 & 16 & 8 & 0 & 0 & 9 & 3 & 5 & 1 \\
\hline Sandvatn & Profundal & 15.08 .12 & 9 & 3 & 3 & 0 & 1 & 0 & 0 & 0 \\
\hline Sandvatn & Profundal & 16.08 .12 & 6 & 0 & 2 & 0 & 1 & 0 & 0 & 0 \\
\hline Sandvatn & Profundal & 14.08 .13 & 39 & 5 & 13 & 1 & 9 & 1 & 11 & 2 \\
\hline Sandvatn & Profundal & 11.08 .15 & 19 & 22 & 3 & 0 & 12 & 4 & 0 & 0 \\
\hline Sandvatn & Profundal & 15.08.16 & 56 & 21 & 18 & 3 & 9 & 1 & 8 & 8 \\
\hline
\end{tabular}

